\title{
Direito à educação, escravatura e ordenamento jurídico no Brasil Império
}

\author{
Right to education, Slavery and legal system in the Brazilian Empire
}

Derecho a l'ducación, esclavitud y ordenamento jurídico en el Imperio de Brasil

\author{
Carlos Roberto Jamil Cury \\ Pontifica Universidade Católica de Minas Gerais (Brasil) \\ Bolsista de Produtividade em Pesquisa do CNPq \\ https://orcid.org/0000-0001-5555-6602 \\ http://lattes.cnpq.br/2686596980826238 \\ crjcury.bh@terra.com.br
}

\section{RESUMO}

Este estudo, documental e bibliográfico, explicita pressupostos do ordenamento jurídico do Império no que se refere à instrução primária e a existência do cativeiro. Aquela era declarada direito da cidadania, mas dela excluía implicitamente os escravos. Aqui se pretende esclarecer melhor o significado jurídico específico dos termos negro, escravo, liberto e ingênuo na abundante literatura sobre a relação educação e escravatura, estabelecendo distinção precisa entre esses termos.Para dar conta desse recorte foram consultadas e revisadas as seguintes bases de dados: Portal de Periódicos, Google Acadêmico e Scielo em artigos, capítulos e dissertações e teses. Campello (2018), pelo estudo do ordenamento jurídico e Jellineck (1912), pela discussão do direito público subjetivo na relação sujeito/Estado foram fundamentais para confirmar, no ordenamento jurídico, a negação da relação positiva entre instrução primária pública e cativeiro.

Palavras-chave: Instrução primária e cativeiro. Instrução primária Pública e Constituição de 1824. 


\begin{abstract}
This documentary and bibliographical study makes explicit assumptions of the Empire's legal system regarding primary education and slavery. This was declared a right of the citizenship. But it implicity excluded slaves. Here its intended to further clarify tke specific legal meaning of the terms black, slave, liberated and ingenuous. To achieve the scope of the article, the following databases were consulted and revised: Portal de Periódicos/CAPES, Academic Google em Scielo in articles, book chapter, dissertations and thesis. Campello (2018), by study of legal system and Jellineck (1912), by the discussion of the subjective public right in the State/Subject relation were fundamental to confirm, in the legal system, the negation of the relationship between primary education and slavery.
\end{abstract}

Keywords: Primary education and slavery. Public instructio and brazilian imperial Constitution.

\title{
RESUMEN
}

Este estúdio, documental y bibliográfico, hace explícitos los supuestos del sistema legal del Imperio brasileño em relación com la educación primaria y la esclavitud. Esto fue declarado um derecho de ciudadanía, pero los esclavos fueron implicitamente excluídos de él. Esto tiene la intención de aclarar aún más el significado legal de los términos negro, esclavo, liberado e ingênuo. Para tener em cuenta este objeto, se consultaron y revisaron las siguientes bases de datos: Portal de Periódicos, Google Acadêmico e Scielo em artículos, capítulos, másteres y tesis. Campello (2018), por el estúdio del sistema legal y Jellineck, por la discusión del derecho público subjetivo em la relacion Sujeto/Estado, fueron fundamentales para confirmar, em el sistema legal, la negación de relación entre educación primaria y cautiverio.

Palabras clave: Educación primaria y régimen esclavp. Instrucción pública y la Constitución de 1824. 
Pancrácio aceitou tudo; aceitou até um peteleco que lhe dei no dia seguinte, por não me escovar bem as botas; efeitos da liberdade.

Machado de Assis. Crônicas.

\section{Introdução}

Este estudo, de caráter documental e bibliográfico, pretende explicitar alguns pressupostos do ordenamento jurídico do Império no que se refere à instrução primária e a existência do cativeiro escravo. O ordenamento jurídico consagrava, na Constituição de 1824 , a instrução primária como direito da cidadania, mas dela excluía implicitamente os escravos. Este estudo pretende tornar manifestos os pressupostos desta exclusão.

A já abundante literatura sobre a relação educação e escravatura, como se verá, pode ainda ser ampliada, no âmbito da produção historiográfica da área, com este recorte específico. Como tal, esse recorte poderá esclarecer melhor o significado jurídico específico dos termos negro, escravo, liberto e ingênuo, com base no ordenamento jurídico.

Há estudos importantes que abordam esse assunto como $O$ filho da escrava (em torno da lei do Ventre Livre) de Mattoso (1988) e Educação dos negros e História da educação de Gondra e Schueler (2008). Outro, é o de Fonseca (2002), especialmente o capítulo 2 em que a Lei do Ventre Livre é tratada diretamente. Na mesma direção, acompanhando a tramitação histórica e legislativa da Lei do Ventre Livre, há a dissertação de Oliveira (2016). Também Cunha (2017) versa sobre escravidão e educação em capítulo substantivo sobre o assunto. E há o Dossiê: Negro e a Educação da Revista Brasileira de História da Educação (2002) que também abriga a temática, bem como o estudo de Gonçalves (2000). Importante é o livro População negra, escravismo e educação no Brasil: séculos XIX e XX de Nogueira (org) (2015) que, entre outros, contém sínteses de estudos versando sobre o escravismo no Brasil, obtidos na Faculdade de Direito - SP para a obtenção do grau de doutor.

Para dar conta desse recorte e de seu valor de modo a agregar um avanço à literatura existente, fez-se um levantamento da produção da área de educação.

As referências bibliográficas identificadas sobre a educação/instrução primária, a partir da Lei do Ventre Livre, fruto de uma pesquisa realizada, no período entre dezembro de 2018 e janeiro de 2019, foi ancorada nas seguintes bases de dados: Portal de Periódicos Capes/MEC, Google Acadêmico e Scielo. Outro processo utilizado para busca de referências sobre a temática foi revisar as referências bibliográficas das obras identificadas nos Portais Científicos. Ressalta-se que os artigos, capítulos e dissertações de mestrado identificados estão disponíveis em formato digital.

Constaram dessa busca os seguintes estudos e pesquisas cujas sínteses se encontram no Anexo: Gondra, 2004; Barros, 2005; Shueler, 2005; Marcílio, 2006; Alves, 2007; Castro, 2007; Moraes, 2007; Rocha, 2007; Veiga, 2008; Cruz, 2009; Souza, 2009; Sebrão, 2010; Veiga, 2010; Silva, 2011; Cândido, 2013; Perussatto, 2014; Stocco, 2016; Xenofonte, 2017; Ribeiro, 2018.

Embora essa literatura cite a legislação sobre esse assunto nem sempre estabelece uma distinção precisa entre esses termos, especialmente entre liberto e ingênuo. Algumas vezes até afirma-se que o ingênuo seria apenas o livre nascido da mãe escrava após a Lei do Ventre Livre, lei n. 2040 de 28 de setembro de 1871. É no que parece incidir o excelente e instrutivo Dicionário de Moura (2013) sobre a escravidão no verbete relativo a "ingênuo". O mesmo não ocorre com o verbete "libertos", cujo teor é pertinente ao conjunto da legislação. Não raro também o termo negro se torna sinônimo de escravo. 
Por outro lado, para que fique clara tal ampliação, há que se recorrer ao conjunto normativo, gradual e específico do período, de que nos dá notícia tanto Campello (2018 e 2018), como Mendonça (2018). O estudo de Campelo (2018) Manual Jurídico é de uma vastidão impar não só pela completa assinalação do conjunto do ordenamento jurídico, como também pelos recursos bibliográficos de caráter contextual a que o autor recorre. $\mathrm{O}$ estudo de Mendonça (2018) sintetiza o ordenamento da época relativo ao emancipacionismo no interior do qual pode-se estabelecer pontes com a educação. Esses autores, incluindo-se a vasta bibliografia de que nos dão notícia, podem auxiliar na melhor compreensão das iniciativas do poder público que ocorreram antes e depois da Lei do Ventre Livre.

Importa também trazer à consideração um conhecimento mais específico do ordenamento jurídico no Império, especialmente a Constituição do período. Está claro, pelo Preâmbulo da Constituição de 1824, que ela foi outorgada pelo Imperador, o que demonstra não se tratar de Constituição proclamada.

A nomenclatura dos dispositivos jurídicos de então difere da dos nossos dias. Recorreu-se, então, ao estudo de Martins Filho (1999) que traz a classificação dos documentos legais e normativos do período e sua nomenclatura. Segundo este estudo esclarecedor, todos os Decretos eram da alçada do Imperador. Há Decretos que sancionavam resoluções da Assembléia Geral Legislativa; e Decretos de caráter executivo, regulamentando as leis ou dispondo sobre a administração estatal. (p. 3) É no Preâmbulo de uns e de outros que se pode distinguir a sua autoria. Já o poder legislativo era exercido pela "Assembléia Geral" (composta pela Câmara dos Deputados e pela Câmara dos Senadores), apreciando os projetos de lei que, uma vez aprovados, eram submetidos ao Imperador sob a forma de Decreto (art. 62) sendo então sancionados como Leis. (p. 3)

Registre-se, como outro ponto importante, dentro de um estudo que toma o ordenamento jurídico como uma de suas fontes, o assinalado por Martins Filho (1999):

Durante o período inicial do Império, os decretos não tinham numeração seqüencial, sendo diferenciados pela data e matéria (e quanto à natureza, pelo preâmbulo). Somente a partir de 1837 é que os decretos começam a ser numerados em duas séries distintas. (p. 3)

As séries se referem às leis e decretos do legislativo e aos decretos próprios do executivo. Alguns atos normativos vindos da Colônia e Reino Unido de Portugal e Brasil, como é o caso de certas disposições das Ordenações Filipinas, entretanto, tiveram vigência durante o período imperial por meio da Lei de 20 de Outubro de 1823:

Art.1o As Ordenações, Leis, Regimentos, Alvarás, Decretos, $e$ Resoluções promulgadas pelos Reis de Portugal, e pelas quais o Brasil se governava até o dia 25 de Abril de 1821, em que Sua Majestade Fidelíssima, atual Rei de Portugal, e Algarves, se ausentou desta Corte; e todas as que foram promulgadas daquele data em diante pelo Senhor D. Pedro de Alcântara, como Regente do Brasil, em quanto Reino, e como Imperador Constitucional dele, desde que se erigiu em Império, ficam em inteiro vigor na parte, em que não tiverem sido revogadas, para por elas se regularem os negócios do interior deste Império, enquanto se não organizar um novo Código, ou não forem especialmente alteradas. 
Art. 2o Todos os Decretos publicados pelas Cortes de Portugal, que vão especificados na Tabela junta, ficam igualmente valiosos, enquanto não forem expressamente revogados.

A Lei do Ventre Livre, em que pese a permanente exigência dos senhores na indenização dos seus cativos, esteve também sob o impacto do que Mendonça (2018) chama de emancipacionismo internacional, de pressão inglesa e de rebeldia escrava. A abolição nos Estados Unidos se deu em 1863 e a abolição no Haiti, produto de uma revolução, ocorreu em 1793, selada com a Independência em 1804. E, segundo essa pesquisadora, a noção de "ventre livre" não era novidade:

Além de ter sido aventada por Pimenta Bueno em 1867, no documento que elaborara a pedido do Imperador, vigia desde 1870 em Cuba, onde a lei Moret havia estabelecido que nenhuma criança nasceria escrava. Muito tempo antes, em 1763, no período pombalino, a medida já fora implementada em Portugal. O preceito do "ventre livre", também tinha orientado a política emancipacionista em várias áreas da América espanhola. Ele vigorou, por exemplo, no Chile, a partir de 1811, na região do Rio da Prata em 1813; em 1821 foi adotado no Peru e nos territórios que se tornariam a Colômbia e a Venezuela. (p. 279-280)

Em nosso caso, o que hoje se tem por direito civil cujo apanágio é a liberdade, estava no capítulo IV das Ordenações Filipinas.

\section{Do direito à educação no Império}

O Direito à Educação no Brasil, enquanto direito à instrução primária pública e gratuita, compareceu, pela primeira vez, em nossa Constituição Imperial de 1824. Essa Constituição, sendo o Brasil, agora, um país politicamente independente, trazia, no seu Título 8o, as Garantias dos Direitos Civis e Politicos dos Cidadãos Brasileiros. Entre eles constava o inciso XXXII do art. 179. Trata-se do art. 179, inciso XXXII dispondo sobre A Instrução primária e gratuita a todos os Cidadãos. ${ }^{1}$ Esta é a versão original retirada da cópia caligrafada retirada do Arquivo Nacional.

Quer dizer que a instrução primária é direito civil e político com as devidas consequências e tem na gratuidade uma de suas garantias.

É fato que, em 1822, antes do Sete de Setembro, o Brasil, como Reino Unido a Portugal e Algarve, era regido pela Constituição Provisória das Cortes de Lisboa. ${ }^{2}$ Assim, o território brasileiro era tido como pertencente à nação portuguesa na América. O futuro Príncipe Regente D. Pedro jurara, junto com D. João VI, em fevereiro de 1821, essa Constituição que ainda estava em elaboração. E havia, nessa Constituição, três artigos referidos à instrução primária como o art. 237, verbis:

\footnotetext{
${ }^{1}$ Há uma pendência ao que se refere à redação desse dispositivo. A outra redação, que também aparece em sites oficiais, é: A instrução primária é gratuita a todos os cidadãos. Nessa versão, os cidadãos que se inscreverem na instrução primária terão a prerrogativa da gratuidade. Na versão citada no corpo do texto, o gozo do direito civil e político denominado instrução primária é facultado a todos, bem como o é a gratuidade. A gratuidade foi inscrita, aqui, como proteção desta etapa da instrução. A versão original da Constituição de 1824 , guardada no Arquivo Nacional é: A Instrução primária e gratuita a todos os Cidadãos.

${ }^{2}$ A promulgação definitiva dessa Constituição se deu em 23/09/1822.
} 
Em todos os lugares do reino, onde convier, haverá escolas suficientemente dotadas, em que se ensine a mocidade Portuguesa, de ambos os sexos, a ler, escrever e contar e o catecismo das leis religiosas e civis.

Por sua vez, o art. 239 dizia:

É livre a todo o cidadão abrir aulas para o ensino público, contanto que haja de responder pelo abuso desta liberdade nos casos e pela forma que a lei determinar.

Esse último artigo corresponde, de certo modo, a um Decreto, o de 10 de março de 1821, assinado por D. João VI em Portugal e publicado no Brasil em 30 de junho de 1821 pelo Príncipe-Regente. Nele se pode ler que, na impossibilidade de a Fazenda Pública estabelecer escolas em todo o Reino:

considerando a necessidade de facilitar por todos os modos a instrução da mocidade no indispensável estudo das primeiras letras (...) querendo assegurar a liberdade que todo o cidadão tem de fazer o devido uso de seus talentos...da publicação deste em diante seja livre a qualquer cidadão o ensino e a abertura de escolas de primeiras letras deste Reino...sem dependência de exame ou de alguma licença.

Tais Constituição e Decreto eram os do Reino Unido. O Decreto de uma liberdade de ensino continuou vigendo, na prática, até a Reforma Couto Ferraz de 1854, sendo Brasil já uma nação autônoma, quando houve limitações a esta franquia. ${ }^{3}$ Assim, a vigência desse Decreto combinava com um dos direitos assegurados em 1824 no art. 179, inciso XXIV da Constituição do Império: nenhum gênero de trabalho, de cultura, indústria ou comércio pode ser proibido, uma vez que não se oponha aos costumes públicos, à segurança e saúde dos cidadãos.

A outorga da Constituição de 1824 foi precedida de uma Constituinte cujos membros foram eleitos. Já é grande o número de artigos e livros sobre este processo. ${ }^{4}$

Com a Constituição de 1824, no Título 80 acima assinalado, a relação entre direito da cidadania e instrução primária já estava aí consagrada, inclusive sob a égide da gratuidade. A gratuidade articulada ao acesso à instrução primária não deixava de ser uma proteção aos direitos listados para esses todos, porquanto o inciso XIII do art. 179 dispunha que a lei será igual para todos, quer proteja, quer castigue, e recompensará em proporção dos merecimentos de cada um. (grifos nossos) $)^{5}$

Mas, quem eram esses todos os cidadãos do inciso XXXII? e quem são os todos do inciso XIII postos no corpo constitucional do art. 179?

Do ponto de vista da inscrição na Lei Maior, eles estão listados no art. 6o nos seus 5 incisos. O foco aqui será o do inciso I.

\footnotetext{
${ }^{3}$ A educação no lar era aceita, até como distinção, por meio de governantas ou do "tio-padre". A Reforma Couto Ferraz de 1854 a admite por conta do art. 18 e do art.64. Leis provinciais, como a do Rio de Janeiro e de Minas Gerais, a inscreveram em seus artigos. A esse respeito, cf. Mendonça e Vasconcelos (2005) e Vasconcelos (2014).

${ }^{4}$ Cf. Mello, 1996; Chizzotti, 1975 e 1996.

${ }^{5}$ Esta expressão: quer proteja, quer castigue é igual à Declaração dos Direitos do Homem de 6 de agosto de 1789 cujo art. 6o dispõe: La loi est l'expression de la volonté générale. Tous les citoyens ont droit de concourir personnellement, ou par leurs répresentants, à sa formation. Elle doit être la même pour tous, soit qu'elle protège, soit qu'elle punisse.
} 


\section{São cidadãos brasileiros: \\ I. os que no Brasil tiverem nascido, quer sejam ingênuos, ou libertos,...6}

O todos, para os quais a lei será igual, são os ingênuos e os libertos. A esses sujeitos, que usufruem do status libertatis são atribuídas as garantias listadas no art. 179, no caso, os direitos civis e políticos.

Portanto, o conceito de ingênuo está subsumido no conceito de cidadania, prerrogativa dos livres. ${ }^{7}$ Já o de liberto, gozando do status libertatis, ficava sob o conceito de cidadania passiva.

Há que se referir ainda ao art. $8^{\circ}$ da mesma Constituição pelo qual suspendem-se os direitos políticos às pessoas com incapacidade física ou moral. Certamente, o que hoje denominamos pessoas com deficiência, muitas delas estariam inclusas nesse impedimento de exercício de um direito.

Cabia aos poderes políticos efetivar os direitos dos cidadãos com as garantias próprias das políticas públicas. É o mandamento do art. 9 dessa Constituição:

Art. 9. A Divisão, e harmonia dos Poderes Políticos é o princípio conservador dos Direitos dos Cidadãos, e o mais seguro meio de fazer efetivas as garantias, que a Constituição oferece.

Se competia aos poderes institucionais, consoante o art. 9 da Constituição, efetivar e garantir os direitos dos cidadãos, no quadro estrutural da sociedade no Império, então será necessário compreender a extensão desse direito, inclusive no âmbito da lei de educação de 15 de outubro de 1827.

\section{A extensão do direito à instrução}

Para efeito de compreensão do âmbito de aplicabilidade desse todos, importa trazer alguns conceitos que se liguem com os direitos civis e políticos da cidadania. Servir-se-á da teoria dos direitos públicos subjetivos de Georg Jellineck (1912), secundada por outros autores. A teoria dos status de cidadania em Jellineck (1912), reitere-se, contém uma tipologia que pode ser importante no esclarecimento desses direitos e, no caso, servir para efeito de compreensão desse todos.

Segundo o jurista austro-alemão (1851-1911), que viveu justamente no final do século XIX e início do século XX, importava trazer à reflexão o sentido de direito público subjetivo como expressão fundante dos direitos civis e políticos. Afirma ele, em seu livro Sistema dei diritti publici subbietivi (1912), que, na relação Indivíduo/Estado própria da Modernidade, o primeiro é um sujeito de direitos pelo que ele tem o poder reconhecido de agir ou não agir (direito subjetivo) garantido pelo ordenamento jurídico e assegurado pelo Estado.

Jellineck (1912) assim define o direito subjetivo:

La volontà è però un mezzo, non un scopo per le finalità, tanto dell'individuo, quanto dell'ordinamento giurídico. Il diritto subbietivo, pertanto è la potestà de volere che ha l'uomo, riconosciuta e protetta

\footnotetext{
${ }^{6}$ A Constituição Política da Monarquia Portuguesa de 1822 tinha os escravos que alcançaram a carta de alforria como cidadãos, consoante o art. 21, IV. Os libertos nascidos em países estrangeiros eram inelegíveis, conforme o art. 34, VII. A rigor, a abolição da escravatura, em Portugal, se deu em 1761.

7 Tenho como hipótese que o termo ingênuo, nascido no Brasil, dotado de cidadania, é assim para se distinguir do termo indígena, que é o nativo originário da terra, também denominado de gentio por ser supostamente selvagem e como tal não civilizado e, não raro, sinônimo de pagão ou seja não batizado. Desse modo, a cidadania do ingênuo, supostamente nascido em uma comunidade civilizada, é uma atribuição jurídica, positivada no ordenamento legal.
} 
dell'ordinamento giuridico, in quanto sia rivolta ad un bene e ad un interesse. ... Volontà ed interesse o bene sono quindi compresi entrambi necessariamente nel concetto del diritto (p. 49) (grifos do autor)

A vontade é, contudo, um meio, não um escopo para a finalidade, tanto do indivíduo, quanto do ordenamento jurídico. $O$ direito público subjetivo, portanto, é a potência de querer que o homem possui, de modo reconhecido e protegido no ordenamento jurídico, enquanto seja endereçada a um bem e a um interesse... Vontade e interesse ou bem são portanto compreendidos necessariamente no conceito de direito.(tradução livre)

Uma vez sujeito de direito e membro de um Estado e, diante do poder estatal, o sujeito entra em relação com o Estado sob várias modalidades.

Norberto Bobbio (1992) ajuda a compreender essa formulação do insigne austríaco quando leciona a respeito da inversão ocorrida na relação Estado/indivíduo com a chegada da Modernidade. Para ele, com o Estado Moderno:

passou-se da prioridade dos deveres dos súditos à prioridade dos direitos do cidadão, emergindo um modo diferente de encarar a relação política, não mais predominantemente do ângulo do soberano, e sim daquele do cidadão em correspondência com a afirmação da teoria individualista da sociedade em contraposição à concepção organicista tradicional. (p. 3)

Dentro desta inversão, Jellineck (1912) aponta quatro modalidades de relação entre o indivíduo e o Estado.

A primeira, denominada status subjectionis ou status passivus, é aquela pela qual o sujeito se subordina aos poderes públicos por meio de deveres, respeitando as leis. Por exemplo, o sujeito deve pagar impostos. Ainda com Bobbio (1992):

O indivíduo singular é essencialmente um objeto do poder ou, no máximo, um sujeito passivo. Mais do que de seus direitos, a tratadística política fala de seus deveres, entre os quais ressalta, como principal, o de obedecer às leis. Ao tema do poder de comando, corresponde -- do outro lado da relação -- o tema da obrigação política, que é precisamente a obrigação, considerada primária para o cidadão, a de observar as leis. (p. 58)

Quando esta relação de sujeição se tornou dominante na História, esteve-se diante do Estado Despótico em que os indivíduos possuem apenas deveres. Já na Modernidade, quando do Estado Absoluto ou Absolutismo, há apenas o reconhecimento dos direitos privados. De todo modo, a tendência das formas autoritárias de governo é a de reforçar a dimensão dos deveres em detrimento dos direitos. ${ }^{8}$

A emersão dos direitos civis foi, historicamente, o modo como os sujeitos buscaram limitar as pretensões despóticas ou absolutistas do Estado.

\footnotetext{
${ }^{8}$ Comparato (2004), referindo-se ao século XVII, leciona: Durante os dois séculos que sucederam à era que se convencionou denominar Idade Média, a Europa conheceu um extraordinário recrudescimento da concentração de poderes. Foi a época em que se elaborou a teoria da monarquia absoluta, com Jean Bodin e Thomas Hobbes, e em que se fundaram os impérios coloniais ibéricos ultracentralizadores. (p. 47)
} 
A segunda modalidade assinalada por Jellineck, denominada status libertatis, ou estado de liberdade, é o gozo que a pessoa, livre das peias da servidão, possui por ser titular dos direitos civis. É aquela prerrogativa de atuação de que o sujeito é titular, em face do Estado, por meio das liberdades individuais como a de expressão, a de crença, a de culto, a de propriedade, de locomoção, entre outras. É também denominada de status negativus. A expressão negativus significa que o Estado não deve interferir nas ações próprias do sujeito. Trata-se do dever de abstenção da parte do Estado em interferir nos espaços das liberdades e a capacidade do sujeito em resistir a imposições indevidas e de o Estado proteger tais direitos como, por exemplo, pelo habeas corpus. ${ }^{9}$

É nesse sentido que, historicamente, houve a conquista de direitos civis. Como diz Jellineck (1912):

gli Stati costituzionali europei, uno dopo l'altro, senza eccezione, hanno intrapeso la ennumerazione di un catalogo di tali diritti.

(...)

Lo scopo legislativo de questa ennumerazione di diritti fondamentali era duplice: essa doveva servire per tutelare la libertá individuale, in quelle determinate sue manifestazione, non solamente contro l'amministrazione dello Stato, e cioe contro costrizione giudiziaria e specialmente contro quella medesima volontà legislativa dello Stato, dalla quale la enumerazione emanava. (p. 106/107)

...os Estados constitucionais europeus, um depois do outro, sem exceção, se comprometeram com a enumeração de um catálogo de tais direitos.

(...)

A finalidade legislativa desta enumeração de direitos fundamentais era dúplice: ela deveria servir para tutelar a liberdade individual naquelas determinadas manifestações, não somente contra a administração do Estado, isso é, contra as constrições judiciárias e especialmente contra aquela mesma vontade legislativa do Estado, da qual a enumeração emanava.

Mais uma vez, Bobbio (1992) explicita um pouco da trajetória deste processo. Segundo ele:

os direitos do homem, por mais fundamentais que sejam, são direitos históricos, ou seja, nascidos em certas circunstâncias, caracterizadas por lutas em defesa de novas liberdades contra velhos poderes, e nascidos de modo gradual, não todos de uma vez e nem de uma vez por todas. (p. 5)

Esses direitos fundamentais receberam uma primeira positivação quando da emersão do do Estado Liberal. ${ }^{10}$ Portanto, a afirmação da liberdade (status libertatis) é a modalidade própria pela qual se fez a afirmação do indivíduo ut singulus, isto é, enquanto indivíduo singular, no Estado Liberal ou seja, aquela concepção de Estado que se fundamenta no indivíduo. De novo, Bobbio (1992):

\footnotetext{
${ }^{9} \mathrm{O}$ habeas corpus ("que tenhas teu corpo") é um instrumento jurídico pelo qual se protege a liberdade de locomoção do sujeito em situação de ameaça ou de lesão. Ele pode se preventivo, quando o caso é de ameaça e suspensivo em caso de detenção. É um dos principais dispositivos dos direitos civis e está presente em nossa atual Constituição no art. 5o , inciso LXVIII, LXIX, LXXII e LXXVII, entre outros.

10 Aqui pode-se fazer uma aproximação com a dimensão dos direitos civis do século XVIII na obra clássica de Marshall (1967).
} 
Concepção individualista significa que primeiro vem o indivíduo singular (o indivíduo singular, deve-se observar), que tem valor em si mesmo, e depois vem o Estado, e não vice-versa, já que o Estado é feito pelo indivíduo e este não é feito pelo Estado...Nessa inversão da relação indivíduo e Estado, é invertida também a relação tradicional entre direito e dever. Em relação aos indivíduos, doravante, primeiro vêm os direitos, depois os deveres; em relação ao Estado, primeiro os deveres, depois os direitos. (p. 60)

A negação histórica desse status é escravidão, chamada de capitis diminutio maxima. Na História da humanidade, houve situações pelas quais grupos livres foram reduzidos à escravidão, como uma condenação penal ou como vencidos na guerra. Nesse caso, trata-se da perda forçada desse status libertatis, uma espécie de "morte civil". A escravidão conflita diretamente com o princípio do próprio termo liberal. Afinal, esse termo, do latim liber = livre, se define como aquele que é senhor de seus atos. A escravidão é um fenômeno contrário à lei natural já que a liberdade se presume, conatural que é a todo ser humano. Como diz Kant (2007):

O homem, e, duma maneira geral, todo o ser racional, existe como fim em si mesmo, não só como meio para o uso arbitrário desta ou daquela vontade. Pelo contrário, em todas as suas ações, tanto nas que se dirigem a ele mesmo como nas que se dirigem a outros seres racionais, ele tem sempre de ser considerado simultaneamente como fim. (p. 68)

Ou do mesmo autor (2007):

No reino dos fins tudo tem ou um preço ou uma dignidade. Quando uma coisa tem um preço, pode-se pôr em vez dela qualquer outra como equivalente; mas quando uma coisa está acima de todo o preço, e portanto não permite equivalente, então tem ela dignidade. (p. 77)

Quando um Estado se proclama Liberal e adota, em sua estrutura social, a capitis diminutio maxima (perda máxima da capacidade jurídica), ele se opõe, dentro de si, ao princípio e à prática da liberdade. Mais do que uma contradição de termos, é uma contradição real de conceito e de prática. Proclamar-se um Estado Liberal e reduzir uma pessoa (persona) à condição de coisa (res) (coisa) é tanto uma contradição, quanto uma violência odiosa. É o caso da nossa Constituição Imperial a qual pelo $\S 22$ do art. 179 consagrava o direito de propriedade por cujo teor os escravagistas postulavam indenização sempre que vinham à tona os projetos, mesmo que parciais, de abolição. ${ }^{11}$

À realidade fática da escravatura no Brasil, pode-se fazer uma ilação e apontar um símbolo desse antagonismo com o princípio de liberdade. Se a nação brasileira, como dizia a Constituição, era resultante da associação política de todos os cidadãos (art. 1o), então os

\footnotetext{
11 Já em 1550, em Valladolid, com a "descoberta" dos índios e com a possibilidade de eles virem (ou não) a se tornarem cristãos, a Igreja Católica afirmava o pressuposto para a assunção do cristianismo: os índios detêm a plenitude da humanidade. A proclamação de Valladolid não atingiu os negros escravizados, e o cristianismo, religião dos filhos do mesmo Pai, teria que justificar essa barbárie! As justificativas, apesar de sua improcedência inclusive teológica, iam desde as pessoas que, por natureza, deviam encarregar-se dos trabalhos duros, tendo que ocupar seu "lugar natural", até a teoria do "mal necessário", a fim de se "libertarem" da "barbárie", passando pelo direito de propriedade do senhor sobre o escravo, considerado como naturalmente desigual. Outra justificativa foi a da evitar a morte de um capturado em guerra. Sobre esse assunto, Cf. Symonides, 2003.
} 
escravos, apesar de serem a força-de-trabalho geradora da maior parte das riquezas do país, não pertenciam a essa associação política. Simbolizando essa exclusão (odiosa), os escravos tinham somente o primeiro nome. O sobrenome, ou era Fulano de tal Senhor, ou, quando batizado, Fulano de Jesus, de Maria, do Espírito Santo, por exemplo. O escravo posto como res (coisa) foi uma prática sustentada por pressupostos (anormais, odiosos e violentos) próprios de uma era pré-moderna ${ }^{12}$. Por sua vez, conclui Campello (2018):

o escravo não poderia ser considerado "Cidadão brasileiro”, pois, se assim o fosse, não poderia, no solo do Império, ser reduzido à condição de cativo, sob pena de violação do art. 179, caput, da Constituição de 1824, bem como do disposto no Código Criminal do Império de 1830...(posição 1159)

Com efeito, esse Código, em seu art. 179, dispunha:

Art. 179. Reduzir á escravidão a pessoa livre, que se achar em posse da sua liberdade.

Penas - de prisão por três a nove anos, e de multa correspondente á terça parte do tempo; nunca porém o tempo de prisão será menor, que o do cativeiro injusto, e mais uma terça parte.

O mesmo Campello (2018), comentando o pensamento de Joaquim Nabuco assim se expressa:

Daí surgem algumas questões: se o escravo não era um Cidadão do Império, seria ele um estrangeiro ou um apátrida? Qual o regime jurídico legal aplicado a eles? Qual o fundamento jurídico para que o Império do Brasil tolerasse que tais indivíduos fossem reduzidos à condição de cativo? (posição 1172) ${ }^{13}$

Ainda nesse sentido, o Código impunha penas aos crimes contra a liberdade individual (Título I da Parte Terceira do Código Criminal onde se aninha o art. 179). Nele se lê o conceito de cativeiro injusto. Ora, isso pressupõe a noção de cativeiro justo. ${ }^{14}$ Do ponto de vista do ordenamento legal, o cativeiro injusto refere-se ao Tratado com a Inglaterra, em 1826, ratificado em 1827, proibindo o tráfico de negros africanos para se tornarem escravos no Brasil, lei entrando em vigor em 1830. A esses se aplicava, na existência fática da escravidão, o conceito de cativeiro injusto da lei, já que as pessoas encontradas sob o tráfico eram livres. $\mathrm{O}$ artigo primeiro da lei de novembro de 1831 dispõe:

Art. $1^{\circ}$ Todos os escravos, que entrarem no território ou portos do Brasil, vindos de fora, ficam livres.

\footnotetext{
12 É evidente um antagonismo com o art. 1o da Declaração dos Direitos do Homem e do Cidadão de 26 de agosto de 1789 da Revolução Francesa: les hommes naissent et demeurent libres et égaux. Já a de 1793, em seu art. 3o declara: Tous les hommes sont égaux par la nature et devant la loi.

13 A esse respeito, sinaliza Campello (2018): Tal regime jurídico do cativo era tão contraditório que o Conselho de Estado do Império teve de se manifestar acerca da situação jurídica dos escravos da Nação que pegaram em armas para lutar contra o Paraguai. Ora, se o escravo não era Cidadão, ele não poderia pegar em armas para defender uma nação da qual ele não era membro. (Posição 1193) Cabia ao brasileiro pegar em armas para defender a nação. Pois assim previa o art. 145 da Constituição. Dessa maneira, o Conselho de Estado atribuiu a alforria ao escravo que tivesse lutado na Guerra do Paraguai.

${ }^{14}$ Para um aprofundamento, cf. Taylor IN : Libby e Furtado, 2006, esp. p. 43-44 ; Mattos e Grinberg, 2018, p. 148 ; Casimiro, 2018.
} 
Para efetivar este mandamento, o Império exarou a Lei de 7 de novembro de $1831^{15}$, também denominada Lei Feijó, inclusive tornando criminoso quem se envolvesse nesse tipo de tráfico. Vale dizer que as pessoas reduzidas à escravidão e traficadas e trazidas ao Brasil recuperavam o status libertatis, ainda que houvesse ações ardilosas para fraudar essa condição. Para tanto, o artigo segundo da lei impõe:

Art. $2^{\circ}$ Os importadores de escravos no Brasil incorrerão na pena corporal do artigo cento e setenta e nove do Código Criminal, imposta aos que reduzem á escravidão pessoas livres, e na multa de duzentos mil réis por cabeça de cada um dos escravos importados, além de pagarem as despesas da reexportação para qualquer parte da África; reexportação, que o Governo fará efetiva com a maior possível brevidade, contrastando com as autoridades africanas para lhes darem um asilo. Os infratores responderão cada um por si, e por todos.

\section{A essas situações aplicava-se o conceito de cativeiro injusto. ${ }^{16}$ Como comenta Campello (2018):}

Como se sabe, essa lei nunca foi posta em execução, porque o Governo brasileiro não podia lutar contra os traficantes; mas nem por isso deixa ela de ser a carta de liberdade de todos os importados depois dessa data. ${ }^{17}$ (...)

.... a lei de 1831 não criava uma disposição transitória; não se limitava a abolir o tráfico; foi além - declarou livres todos os escravos importados de então em diante. Tal disposição é, de sua natureza, irrevogável; a liberdade, uma vez adquirida, nunca mais se pode perder. Os importados depois de 1831 adquiriram-na, por disposição expressa de lei, nunca foram escravos no Brasil ...(p.9)

Em outro trecho deste autor, pode-se deduzir que os filhos destes livres eram igualmente livres.

se a partir de 1831, qualquer escravo que, após o advento desta lei fosse importado e viesse a ser desembarcado no Brasil seria considerado como homem livre, logo, pode-se concluir que somente poderiam ser considerados cativos em território brasileiro, os filhos de mães e pais escravos que houvessem chegado ao território brasileiro, anteriormente a este diploma legislativo. (p. 10)

\footnotetext{
${ }^{15}$ Sobre a lei de 1831, cf. Mamigonian e Grinberg, 2018.

16 A noção oposta, a de cativeiro justo, se aplicava à aceitação da escravatura como "mal menor" ou "mal necessário" e, como tal, deveria este estatuto ser submetido às regras da caridade cristã. A essas regras, aos poucos, a presença interveniente do poder público imperial introduziu novas que impunham alguns limites à atuação dos senhores, ou seja, a escravidão passou a contar com maior regulação do Estado. Sobre essa regulação, cf.Mendonça, 2018.

${ }^{17}$ Sobre Cartas de Liberdade, Moura (2013) explica as categorias delas em Minas Gerais: a) as conseguidas por gratidão; b) as concedidas sob condição; $c$ ) as vendidas a escravos ou pagas por alguma associação; d) as concedidas a crianças, filhos de escrava com o senhor e pai da criança; e) as concedidas em favor de determinado escravo, para lhe ser entregue após a morte do senhor. (p.89)
} 
Essas pessoas, portanto, eram livres e não libertos e se contrastavam com os africanos negros que foram trazidos à força para o Brasil para se tornarem escravos. Contudo, importa reter a observação de Mamigonian e Grinberg (2018):

A intenção era a de que os africanos assim emancipados fossem "reexportados", ou seja enviados de volta à África às custas dos importadores. (p. 286)

O decreto de 12 de abril de 1832 foi exarado no sentido de regulamentar a lei de 1831, em especial, na fiscalização dos navios que tivessem suspeita de estarem traficando. ${ }^{18}$ Segundo Campello (2018), um "estatuto civil" dos escravos só viria com a Lei de Ventre Livre de 1871:

Evidente que, ao longo dos anos, a regulamentação da vida civil sofreu alterações, com o advento da Lei do Ventre Livre (Lei $n^{\circ} 2.040$, de 28 de setembro de 1871), a qual estabeleceu verdadeiramente um Estatuto Civil para o elemento servil, revogando a legislação anterior. Mesmo assim, trata-se de um diploma legal que apenas concedia "direitos civis" com a finalidade de manter um regime exploratório que já perdurava há mais de 300 anos no solo brasileiro. (posição 3523-3524)

Mamigonian (2011) aponta para uma outra dimensão implícita na lei do Ventre Livre. Segundo essa autora:

Governo e proprietários evitavam, a todo custo, dar publicidade ao direito dos africanos à liberdade com base na lei de 1831, e quando a Questão Christie e a agitação política da década de 1860 o fizeram eles abraçaram a proposta gradualista como solução para evitar a emancipação imediata e dar, mais uma vez, sobrevida à escravidão. (p. 37)

A terceira relação estabelecida por Jellineck (2012) é o status activae civitatis ou status activus. Ela indica o estatuto do cidadão pelo qual este pode participar das decisões políticas de sua comunidade, como, por exemplo, o direito de eleger e de ser eleito. Aqui dáse o exercício do voto pelos direitos políticos uma vez que o sujeito é reconhecido como pertencente ao Estado. Diz Jellineck (2012):

Ogni azione statale è azione nel publico interesse. L'interesse generale non è assolutamente necessario che coincida, ma può coincidere con l'interesse individuale. In quanto tale ultima ipotesi si verifica e la coindidenza è riconosciuta dallo Stato, questo accorda all'individuo pretese giuridiche (Ausprüche) all'attività statale e

\footnotetext{
18 No capítulo escrito por Mamigonian e Grinberg (2018), dá-se conta de que houve iniciativas no Parlamento tendentes a revogar a lei de 1831. Embora não se atingisse esse objetivo, a lei n. 581 de 1850 , mais conhecida como Lei Eusébio de Queirós, reitera a repressão ao tráfico, conquanto se mantivesse a escravidão. A importação de escravos foi declarada pirataria, de acordo com o artigo 4o da mesma. O tráfico de fora foi praticamente extinto. Mas o tráfico interno cresceu até 1881. A lei n. 581 foi regulamentada pelo Decreto n. 731 de novembro de 1850. A lei n. 3.270 de 1885 interditou a alteração domiciliar dos escravos, pondo um fim legal ao tráfico interno. Acrescente-se a isso o processo de colonização para o qual se valeu da força-de-trabalho estrangeira tão logo se publicou a Lei de Terras, lei n. 601 do mesmo ano de $1850 \ldots$ após a lei n. 581. Por aí se constata o quão gradual foi o processo de Abolição e a continuidade de uma exclusão em outros parâmetros.
} 
mette a dispozione de lui remedi giuridici per realizzarla. In questa manera lo Stato eleva l'individuo alla condizione di membro della comunità statale dotato di facoltà aventi carattere positivo, gli confirisce lo status di cittadinanza...(p. 127)

Toda ação estatal é ação para o interesse público. O interesse geral não é absolutamente necessário que coincida, mas pode coincidir com $o$ interesse individual. Enquanto esta última hipótese se verifica e a coincidência é reconhecida pelo Estado, este consente ao indivíduo reivindicações jurídicas (Ausprüche) à atividade estatal e põe à disposição dele remédios jurídicos para satisfazê-la. Desse modo, o Estado eleva o indivíduo à condição de membro da comunidade estatal dotado da faculdade de ter um caráter positivo, lhe conferindo o status de cidadania.

Em outros termos, segundo o mesmo autor:

....all 'individuo viene attribuito un nuovo status, che è lo status activae civitatis, o, più brevemente, status attivo. (p. 154)

...ao indivíduo vem atribuído um novo status, que é o status activae civitatis, ou, mais brevemente, status ativo.

Aqui estamos no campo do Estado Democrático cujo sustentáculo é a participação, participação política como eleitor, como postulante a ser eleito e como membro de outras associações coletivas. ${ }^{19}$

Bobbio (1986) aponta a sexta promessa não cumprida com relação à cidadania:

Nos dois últimos séculos, jamais esteve ausente o argumento segundo o qual o único modo de fazer com que um súdito transforme-se em cidadão é o de lhe atribuir aqueles direitos que os escritores de direito público do século passado tinham chamado de activae civitatis; com isso, a educação para a democracia surgiria no próprio exercício da prática democrática.(p.31)

A perda deste status é chamada de capitis diminutio media. Ou seja, retém-se a liberdade, mas se é excluído da vida política. Como diz Bovero (2002):

Dela poderíamos deduzir -- como alguns fizeram -- uma verdadeira independência entre a condição do homem livre e a condição do cidadão, ou ao menos a efetiva possibilidade de separação entre o status libertatis, definido por determinados direitos não ligados à integração do indivíduo na civitas, $e$ o status civitatis, definido por outros direitos propriamente ligados à pertença do indivíduo a uma comunidade. (p. 124)

É o caso dos libertos, na Constituição Imperial, entre outras restrições, impedidos de $\operatorname{votar}^{20}$ para além das eleições municipais.

\footnotetext{
${ }^{19}$ O status ativo aproxima-se do conceito de direitos políticos do século XIX tal como desenvolvido por Marshall (1967).

20 Tal é o caso, hoje, dos apenados cujo processo já transitou em julgado. O art. 15 da Constituição de 1988 os impede de votar enquanto estiverem no cumprimento da pena.
} 
A outra relação Estado/sujeito se dá pelo status civitatis. Como diz Jellineck (1912):

La uguaglianza di diritto consiste perciò essenzialmente nela uguaglianza, per lo meno in massima, dello status positivo. (p. 150).

A igualdade do direito consiste, portanto, essencialmente na igualdade, pelo menos como norma de conduta, do status positivo.

Esse é o campo do Estado Social. Trata-se da prestação devida pelos poderes públicos aos sujeitos no preenchimento de determinadas necessidades e no acesso a determinados bens de modo que estes mesmos sujeitos possam fazer opções, reduzindo as necessidades, ampliando sua liberdade pela capacidade de escolhas. Trata-se dos direitos sociais pelos quais se postula um papel positivo do Estado na redução das desigualdades e na ampliação da igualdade. ${ }^{21}$

Um desses bens é o acesso à educação pelo princípio da igualdade de oportunidades.

Fica evidente que o ordenamento jurídico imperial é claro com relação ao status subjectionis, já que os deveres compõem o ordenamento jurídico. Mas os outros status estão condicionados pelo estatuto da escravidão. Ele antagoniza com o status libertatis e suas decorrências. Ao mesmo tempo, representa uma limitação aos libertos, por sua condição de cidadania passiva. No caso da instrução primária pública, em que pese a gratuidade, não se pode trazer como seu o princípio da igualdade de oportunidades.

Pelo exposto, torna-se possível entender o estatuto dessas duas categorias de pessoas, as assim classificadas como ingênuos e libertos, e suas respectivas distinções. Enquanto gênero, isto é, enquanto uma categoria geral que abarca ambos os sujeitos, estão contemplados no termo todos do artigo 179 da Constituição Imperial. Nesse sentido, gozam do status libertatis e, como todos os outros, estão sujeitos a deveres. Mas enquanto categorias, distintas na espécie, como apontar-se-á mais adiante, terão direitos diferenciados no que se refere ao status activus. Como dito por Campello (2018)

Dispor sobre a escravidão em uma Constituição liberal seria uma contradição, entretanto, o legislador constituinte encontrou uma saída: implicitamente, fez referência aos cidadãos brasileiros libertos, isto é, aqueles que emergiram da capitis diminutio maxima, passando a gozar de seu status libertatis, mas sem alcançar o mesmo status civitatis dos cidadãos brasileiros ingênuos. (posição 1124-1125)

Além de ingênuos e libertos, a estrutura social vigente pós Independência abrangia os senhores, burocratas, os brancos e mestiços não proprietários, os escravos e os indígenas. ${ }^{22}$

Os indígenas, conquanto não sejam objeto deste recorte, não foram mencionados na Constituição de 1824, embora tenham sido objeto de debates na Constituinte. ${ }^{23}$ Houve, contudo, muita legislação a respeito da "civilização e catequese" dos indígenas durante a Colônia e o Império. Esses já tinham sido considerados livres pelo Diretório dos Índios de 1755, pelo qual D. José I e o Marquês de Pombal regulam os aldeamentos indígenas. Desse

\footnotetext{
${ }^{21}$ De novo, torna-se possível a aproximação com a noção de direitos sociais trabalhada por Marshall (1967).

${ }^{22}$ Souza (2017) reflete sobre a constituição de uma camada branca ou mestiça não-proprietária. Para ele: passa a operar um novo código social nascente, uma nova "hierarquia social" que vai estipular os critérios que permitem e legitimam que alguns sejam vistos como superiores e dignos de privilégios, e outros sejam vistos como inferiores e merecedores de sua posição marginal e humilhante... a posse, real ou suposta, de valores europeus individualistas vai, dessa forma, justificar os privilégios de um sobre o outro, calar a injustiça a consciência da injustiça ao racionalizá-la e permitir a pré-história da naturalização da desigualdade... (p. 71-72)

${ }^{23}$ A Constituição Política da Monarquia Portuguesa de 1822 dispunha sobre os índios no art. 243.
} 
modo, apesar do status libertatis, advindo desde a época pombalina, a proposta de civilização e de tomá-los como vivendo em estado barbárie, os coloca dentro de uma "escala civilizatória" na qual ainda não teriam chegado ao ponto de serem considerados "civilizados". Nessa escala, um ponto de inflexão seria a conversão do "gentio" (pagão) ao catolicismo. A regra de número 10 do Diretório proíbe chamar os índios de negros, pois se trata de uma infâmia, vileza e abominável abuso. Ademais, consoante o mesmo ordenamento, são termos prejudiciais à civilidade dos índios.

E havia, na composição populacional do Brasil, os escravos. O Império trouxe consigo a escravidão como herança (Título do Capítulo 1 de Campello, 2018):

o Título XVII, Livro IV, das Ordenações Filipinas, concedia ao escravo africano a natureza de coisa comercializável, reduzindo-o a um mero bem, que poderia ser transferido de um proprietário para outro... (posição 602)

Tomando-se o inciso I do art. 179, tem-se então, por meio de um raciocínio implícito, que a Constituição admite a existência de escravos. Eles representam um outro modo de ser e de compor com o todos sem usufruir da natureza própria da cidadania. Ribas, em 1880, ainda que afirmando o caráter contrário à natureza da existência do escravo, constata:

Não tratamos agora do caso em que, contrariando a natureza, attrahimos para essa esphera a pessoalidade inteira de outros entes livres, e estabelecemos sobre elles o nosso imperio absoluto, porque então ficão elles despessoalisados, reduzidos ao estado de cousas, e denominão-se escravos. (p. 327)(grifos do autor)

Como afirma Campello (2018):

Pode-se concluir que, se a própria Constituição imperial atribuía a condição de cidadãos apenas àqueles indivíduos que se apresentavam como ingênuos ou libertos, era porque esse diploma admitia, ao menos tacitamente, a possibilidade de que no território do Império, outros indivíduos não pudessem ser cidadãos por não possuírem este status libertatis, ou seja, porque eram escravos A Constituição imperial não declarou explicitamente a existência da escravidão no território nacional, mas poderia se inferir que ela fazia parte da estrutura jurídica brasileira. (Posição 1135)

Um outro indicativo da permanência da escravatura pode ser lido no mesmo artigo 179, inciso XIX da Constituição Imperial de 1824.

XIX. Desde já ficam abolidos os açoites, a tortura, a marca de ferro quente, e todas as mais penas cruéis.

É certo que tais crueldades faziam parte de castigos aplicados aos escravos. Apesar disso, o art. 60 do Código Criminal do Império de 1830 previa a pena de açoites bem como a lei n. 4 de 1835 e o parágrafo $2^{\circ}$ do Título LX do livro V das Ordenações Filipinas. Campello (2018) comenta esta situação:

Para solucionar tal antinomia, a doutrina jurídica do período realizava a harmonização destes objetivos alegando que o art. $179 \mathrm{da}$ 
Constituição Imperial assegurava direitos fundamentais e liberdades públicas tão-somente aos "Cidadãos Brazileiros"... (p. 17) ${ }^{24}$

Importa, pois, esclarecer, até por oposição implícita a escravos, o que, à época, significavam ingênuos e libertos.

Eram declarados ingênuos aqueles nascidos livres. Eles estão declarados no artigo 6o da Constituição.

A origem etimológica de ingênuo vem do latim: $i n=$ dentro e genuus $=$ nascido. $\mathrm{A}$ etimologia converge com Bueno (1988, p. 1929) que nos indica que ingênuo é aquele nascido no país, natural do país em que vive. Afora essa correlação cidadania/nação, própria da Constituição dos Estados Nacionais, ingênuo, segundo o Direito Romano, abrangia quem já nasceu livre, isto é, de pais (pai e mãe) livres. Esse é um dos significados trazidos por Houaiss (2009, p. 1083) no verbete: no direito romano, que ou quem já nasceu livre.

De acordo com este Direito, a máxima partus sequitur ventrem significa que a descendência segue a condição da mãe. Segundo Moura (2013), no caso da mãe escrava:

Isso tirava o direito da mãe ao filho, fosse ele gerado por relacionamento com homem livre ou não. O mesmo não acontecia quando um escravo fazia filho numa mulher livre. (p. 237)

Assim, dada a existência real da escravatura no país, por este princípio, o filho da escrava nasce escravo, ainda que o pai seja livre. Como assevera Santos (2016):

The Roman principle of partus sequitur ventrem had a longstanding tradition in Portuguese America and Brazil. Yet, it was precisely when the hereditary reproduction of slavery through enslaved women's bodies became a focal point of debate that slaveholders deployed this notion as the fundamental validation of the right of slave owners to hold people of African descent and their offspring as human property. (n.p)

O princípio Romano do partus sequitur ventrem teve uma longa tradição na América Portuguesa e no Brasil. Então, precisamente quando a reprodução hereditária da escravidão, por meio dos corpos das mulheres escravas, tornou-se um ponto focal do debate foi que os proprietários de escravos se ativeram a este princípio como a validação fundamental do seu direito de considerar os africanos $e$ seus descendentes como propriedade humana.

Também Mattos e Gringberg (2018) afirmam:

Ambos os impérios, português e espanhol, possuíam códigos legais unificados, baseados no direito romano, que tanto regulavam a escravidão como favoreciam a alforria. Durante o período islâmico e medieval, os espanhóis e os portugueses mantiveram um pequeno número de escravos em suas populações. Conseqüentemente, o corpo de direito regulava os escravos tanto como propriedade quanto como pessoas. Essas leis foram transplantadas -- muitas vezes também

\footnotetext{
${ }^{24}$ Este odioso artigo foi revogado pela lei n. 3.310 de 1886, bem como a lei n. 4 de 1835. Essa última também regulava a aplicação da pena de morte e de açoites aos escravos.
} 
adaptadas para os contextos específicos -- para as colonias portuguesas e espanholas nas Américas. (p. 163)

Desse modo, não sendo considerados livres (porque escravos) e, por consequência, não considerados cidadãos, os nascidos sob o princípio partus sequitur ventrem (ventre escravo gera descendência escrava) não fazem parte da civitas. Voltando a Bovero (2002):

para os escravos não há polis, ou seja, cidadão pode ser apenas o homem livre; e invertendo os termos, homem livre pode ser apenas o cidadão, integrado em alguma civitas, "pertencente" a uma comunidade. (p. 125)

E, desse modo, também não eram admitidos na instrução primária pública da lei geral de educação de 15 de outubro de 1827.

Isto se confirma tanto pela Reforma Couto Ferraz do Decreto n. 1331-A de 1854, quanto por várias leis provinciais de instrução primária. ${ }^{25}$

A Reforma Couto Ferraz dispõe:

Art. 69. Não serão admitidos à matricula, nem poderão freqüentar as escolas:

$\S 1^{\circ}$ Os meninos que padecerem moléstias contagiosas.

$\S 2^{\circ}$ Os que não tiverem sido vacinados.

$\S 3^{\circ}$ Os escravos. ${ }^{26}$

É, igualmente, o caso da lei provincial de Minas Gerais, lei n. 13 de 28 de março de 1835 que assim dispunha:

Somente as pessoas livres podem freqüentar as Escolas Públicas, ficando sujeitas aos seus Regulamentos.

Importa registrar o adjetivo públicas que acompanha o substantivo escolas. Outras formas de educação, portanto, não estavam proibidas. Veiga (2008) traz uma importante observação a este respeito em Minas Gerais:

é possível encontrar registros da cor dos alunos e de freqüência de escravos; não identifiquei nenhum documento posterior com tais dados. Minha interpretação é de que somente a partir da lei provincial $n .13$, de 1835, é que fica realmente oficializado em Minas Gerais o impedimento de os escravos freqüentarem uma aula pública, embora não haja restrições a aulas particulares, havendo até uma lei que possibilitava tal acesso.(p. 510)

Uma indicação dessa possibilidade é dada por Salles (2007) apontando a função das confrarias em Minas Gerais como canalizadoras dos anseios e das aspirações dos seus membros:

\footnotetext{
${ }^{25} O$ Decreto n. 7.247 de 1879, Reforma Leôncio de Carvalho, posterior à Lei do Ventre Livre de 1871, não reproduz a proibição de acesso dos escravos às escolas públicas.

${ }^{26} \mathrm{O}$ art. 62 desse Decreto também tinha um outro vetor: Se em qualquer dos distritos vagarem menores de 12 anos em tal estado de pobreza que, além da falta de roupa decente para frequentarem as escolas vivam em mendicidade, o Governo os fará recolher a uma das casas de asilo que devem ser criadas para este fim... $\mathrm{O}$ Decreto ainda dispunha, no art. 63, que essas crianças, uma vez tendo recebido a instrução primária, deveria ser encaminhadas para as companhias de aprendizes dos arsenais...
} 
No entanto, em Minas do século XVIII, embora conservando esta finalidade inicial, as confrarias se projetam numa atividade muito mais ampla, quase transformando a corporação religiosa em certa estrutura formal ou orgânica, cujo conteúdo principal se expressa na formulação da assistência social e securitária adequada ao meio e à época. (p. 119)

Entrementes, no caso de outras legislações provinciais, é de Barros (2016) um levantamento amplo sobre semelhante proibição posta pela lei provincial de Minas Gerais. Segundo o levantamento da autora, aplica-se a proibição a Goiás, Espírito Santo, Rio Grande do Norte, Mato Grosso, Paraíba, Pernambuco, Rio Grande do Sul, Maranhão e Paraná.

A lei provincial n. 8 do Rio de Janeiro, datada de 2 de maio de 1837, estabelecendo o regulamento da instrução pública primária na Província, estabelecia em seu art. 39:

Somente as pessoas livres podem frequentar as escolas públicas, ficando sujeitas ao seu regulamento.

Com efeito, como se viu, a Constituição Imperial não trata diretamente da escravidão e a lei geral de 1827 não se refere aos escravos e também não é explícita com relação a uma proibição de os escravos frequentarem escolas públicas.

Esta proibição (implícita) tinha um espectro mais amplo e paradoxal, como expressam Mattos e Grinberg (2018):

O paradoxo de os escravos serem, juridicamente, coisa e pessoa ao mesmo tempo persistiu durante toda a vigência da escravidão brasileira. De fato, segundo o direito colonial português, o escravo era considerado um bem semovente, definido em termos jurídicos como uma coisa, privado de direitos, impedido de possuir propriedade e incapaz de manter qualquer obrigação. No entanto, o mesmo corpus legislativo que permitia a um homem a posse e a propriedade por outro, negava aos senhores o direito de vida e morte sobre seus escravos, punia aqueles que os castigavam em demasia, $e$ consideravam que o escravo devia responder pessoalmente pelos crimes que porventura viesse a cometer. (p. 164)

Portanto, o escravo era uma "coisa", um "objeto" animado, sem direitos, um ser ausente, (por não ser considerado como sujeito de direitos) mas, na hipótese de um crime tornava-se pessoa a fim de responder pelo seu ato.

Comentando a legislação imperial sobre condutas criminosas no processo penal ${ }^{27}$, diz Campello (2008):

para o direito imperial, o servus, apesar de não ser cidadão brasileiro, poderia se inserir em algumas relações jurídicas. Conclui-se que, para a legislação brasileira, o escravo era um sujeito de direito cuja capacidade jurídica estava minorada, ... o escravo poderia ser sujeito de relação jurídica penal, sobretudo na condição de agente. (p. 13)

\footnotetext{
${ }^{27}$ Cf. Lei de 29 de novembro de 1832 que promulga o Código de Processo Penal.
} 
Desse modo, reforce-se, a manutenção das Ordenações Filipinas como substitutivas de um Código Civil, tinham os escravos como "coisas", já o Código Penal do período os tinha como "pessoa", em face de condutas inscritas como criminosas, a fim de responder pelos seus atos. Essa realidade expressa a violência da escravatura em face de um regime formalmente liberal. Tal violência não só precedeu a Independência e o estatuto liberal disposto em 1824, como condicionou este estatuto pelas bases socioeconômicas que o sustentavam. A tal ponto que o escravo poderia ser vendido, doado, alugado, hipotecado, penhorado e dado como herança. A violência e a brutalidade imperavam no centro das relações entre dominus e servus.

Em 1869, o Decreto n. 1.695 proibiu a venda de cativos, em leilões, com exibição pública, sob pena de nulidade. Consoante o art. $2^{\circ}$ :

Em todas as vendas de escravos, ou seja particulares ou judiciais, é proibido, sob pena de nulidade, separar o marido da mulher, o filho do pai ou mãe, salvo sendo os filhos maiores de 15 anos.

Entretanto, isso não quer dizer que, na dialética do senhor e do escravo, esse último fosse um ser passivo, apesar de ser considerado res, propriedade de outro. Como leciona Silva (2000), os escravos jamais se coisificaram:

Nem foram passivos e conformados com os inegáveis sofrimentos aos quais estavam submetidos, nem tampouco foram rebeldes extremados. Eles usaram os elementos e as estratégias previstas e disponíveis na sociedade escravista, forçando a criação de espaços de liberdade em meio ao cativeiro, construindo várias "visões de liberdade"... (p. 103) (grifos da autora)

É preciso notar que, ao lado das irmandades religiosas de brancos, havia as de negros e pardos. ${ }^{28}$ Assim, a fim de não confundir os termos, cumpre trazer importante anotação de Veiga (2008):

Ao tomar negros por escravos, estudiosos acabam por limitar a discussão sobre o lugar da escola pública na organização das nações modernas e dos Estados constitucionais. (...)Sobre a escolarização de negros e mestiços ao longo do século XIX, poucos estudos foram realizados de maneira que dessem visibilidade a uma outra possibilidade de vida dos afrodescendentes que não associada ao mundo da escravidão ou da marginalidade.(pg.503)

Estratificadas pela dimensão racial, característica explorada por Salles (2007) no Brasil Colônia, as irmandades religiosas mantiveram tal perfil no período imperial. Para este período, também são válidas as conclusões do estudioso:

Como à Coroa interessava a fundação das irmandades, as camadas sociais se aglutinavam no seio delas, passando a usá-las como associações de interesse grupal. Não quer dizer isso que a irmandade perca ou reduza suas funções religiosas ou chamadas piedosas. (p. 72)

Nesse sentido, Salles (2007) completa dizendo que as confrarias:

\footnotetext{
${ }^{28}$ Sobre irmandades e confrarias em Minas Gerais, cf. Boschi, 1986
} 
proporcionaram às camadas humildes e pobres do tempo um meio de luta, revelando a esses grupos a possibilidade jurídica dessa luta e a relatividade desse jurídico, isto é, relatividade da justiça e sua feição temporal ou histórica;

não havendo sistema educacional, as irmandades educaram através de um convívio disciplinado, no próprio organismo, pelos sermões e pelo contato direto com os padres, grande número de trabalhadores, escravos e livres. Mostraram a esses grupos oprimidos que as soluções para seus problemas estavam na organização estrutural deles... (p. 178)

Essa dimensão é corroborada por Wissenbach (2018):

verifica-se a difusão dos mesmos hábitos de letramento entre grupos de escravizados pertencentes às ordens religiosas e ao clero que, como senhores, demonstravam relativa preocupação quanto às condições de vida dos grupos escravizados, instruindo-os profissionalmente, insistindo na manutenção de famílias e na educação religiosa. Por fim, é possível associar a cultura escrita a situações específicas do trabalho urbano, principalmente aos ofícios que exigiam dos cativos um desempenho autônomo. Nesse caso, tanto a escrita como a capacidade de contabilizar estariam ligadas não só às regalias, como também às exigências de um mercado de trabalho competitivo no qual os cativos seriam obrigados a agenciar os serviços por conta própria. (p. 294)

Por outro lado, sobre o acesso à leitura e à escrita, continua Wissenbach (2018):

A prática da escrita, quando exercida por escravos e escravas, libertos e libertas, principalmente na atmosfera das sublevações sociais da década de 1870 e 1880, não só levantava suspeita, como denotava uma atitude de arrogância, uma vez que, na visão da sociedade hegemônica, pressupunha o uso de um código que se mantinha privilégio exclusivo da elite e que não fazia parte dos atributos pensados para a classe dos escravizados. (p. 295)

Em direção semelhante caminha o estudo de Gondra e Schueler (2008):

É possível, então, pensarmos na hipótese de que a proibição das matrículas aos chamados "pretos africanos livres e libertos" tenha sido motivada pelo medo das elites senhoriais em relação aos perigos da propagação das letras entre os africanos livres, o que poderia acalentar sonhos de liberdade não apenas nestes indivíduos submetidos ao regime da lei de 1831, mas também despertar inconvenientes inquietações entre os escravos crioulos nascidos no Brasil. (p. 242)

Ao lado desses meios internos de busca de acesso à escrita e à leitura, é preciso apontar as fugas, os abortos, as rebeldias, os quilombos e mesmo os crimes contra os 
senhores, além de movimentos coletivos, como expressões de um status ativo mesmo que não reconhecido como tal. ${ }^{29}$ É o que afirma Campello (2018)

Igualmente distorcida é a perspectiva de que a escravidão era passivamente aceita pelos escravos, urbanos ou rurais, e que tais relações se assentavam em um ambiente de cordialidade entre senhores e servos, sempre de forma paternalista ou de franca $e$ respeitosa camaradagem. Longe disso, a escravidão era uma relação social que, por meio de sua violência (potencial ou efetiva, mas sempre presente), brutalizava toda a sociedade, tornando-a quase insensível a um problema que atingia milhões de indivíduos que viviam no cativeiro, muitas vezes ilicitamente.(Posição 248-249) os cativos:

Em outra passagem, Campello (2018) dá uma indicação de como direito penal via

Por essa razão, a melhor maneira de interpretar a legislação penal aplicada em face de crimes perpetrados pelos cativos é vê-la, de fato, como um evidente Direito Penal do Inimigo. (posição 4878) ${ }^{30}$

Em outra chave, a proibição do acesso às escolas públicas pode assim ser lida: a de que este interdito tinha um sentido de resguardo contra possíveis demandas, pressões e outras modalidades de reivindicações. ${ }^{31}$ Como assevera Silva (2000):

Aprender a ler e escrever, enfim, podia permitir aos escravos africanos e crioulos (escravos brasileiros) passarem como libertos ou exercerem ofícios que os aproximassem da experiência da liberdade. Some-se a estas possibilidades, ainda uma outra: a possibilidade de travar contato com as letras dos homens de cor que, a partir de 1830, na Corte, criaram jornais específicos nos quais discutiam questões referentes à raça, identidade e mobilidade social...(p. 112 - grifos da autora $)^{32}$

Para Albuquerque (2018), escrevendo sobre os profissionais das tipografias:

Esses profissionais criticavam a falta de empenho do governo imperial para garantir a instrução aos "ingênuos" prevista na lei de 1871. (p. 330)

${ }^{29}$ Cf. Algranti, 1988; Azevedo, 1987, Cardoso, 2002 , Gonçalves, 2000 e Albuquerque, 2018

${ }^{30}$ A teoria do Direito Penal do Inimigo, elaborada pelo jurista alemão Gunter Jakobs em 1985, extremamente polêmica, se aplicaria a criminosos tidos como inimigos do Estado ou da Sociedade, que não deveriam ser tratados pelo direito penal comum a cidadãos, mas por um direito penal diferenciado adequado a inimigos, já que não ofereceriam garantias de que se comportarão de acordo com o ordenamento jurídico. A lei n. 4 de junho de 1835, lei de terror em defesa do escravismo, que em rito sumário, levava os cativos à pena capital, aproxima-se dessa versão defendida por Jakobs.

31 Sobre a distinção entre escravos, negros e mestiços na educação imperial, cf. Veiga, 2008, 2010.

32 Silva (2000) traz à luz uma situação muito elucidativa desta consciência da importância da educação escolar como que buscando efetivar, em decorrência de uma visão de liberdade, nos termos de Castro (1995) uma prática de liberdade. Trata-se da demanda de um professor negro, de nome Pretextato dos Passos e Silva, dirigida à Inspetoria Geral da Instrução Pública da Corte, da abertura de "uma escola para meninos pretos e pardos" a fim de que pudessem "aprender com perfeição e sem coação “. Segundo interpretação de Silva (2000): ...há uma possibilidade real de que a escola de Pretextato tenha sido uma expressão da luta dos libertos e seus descendentes pelo acesso à educação formal, escolarizada ... (p. 141) 
Ainda é Silva (2000) que conclui:

aos escravos coube a árdua tarefa de ir abrindo os caminhos da liberdade em meio à escravidão, procurando mantê-los sob seu controle e correndo o risco de perdê-los a qualquer momento. E para os libertos tratou-se de, em conseguindo a obtenção do status jurídico de "livres", procurar afastarem-se, o máximo possível, do passado cativo, em que pese este afastamento fosse, e é até hoje, limitado pelo estigma da cor. (p. 141)

Sem uma alteração significativa na estrutura socioeconômica, pode-se dizer que, na Independência, houve uma "revolução vinda de cima", nos termos de Moore Jr (1975), ou de uma "revolução passiva" nos dizeres de Gramsci. Os grupos anteriormente dominantes ficaram como tais, ocupando o centro do poder de Estado. É nesse sentido que houve uma negação de direitos a significativa parte do todos de que derivou um odioso processo de exclusão. Resulta daí que não se pode afirmar a universalidade do todos disposto na Constituição Imperial.

O princípio do partus, de acordo com Santos (2016), foi bastante disseminado após 1830, quando da proibição do tráfico de escravos após o Tratado Internacional assinado entre Brasil e Inglaterra, em 26 de novembro de 1826. Por este Tratado, negros africanos encontrados em navios de tráfico estavam ipso facto emancipados, vale dizer, livres. $\mathrm{O}$ mesmo se aplicava àqueles que, em território nacional, fossem vindos em navios de tráfico e identificados como tais. Pela lei de 7 de novembro de 1831, todos os escravos vindos de fora do Império recuperam sua condição de liberdade. O caráter deste dispositivo está expresso de tal forma que tais pessoas jamais foram escravos e, portanto, se houve tráfico (clandestino) após esta lei (e houve), os aqui chegados como se escravos fossem, livres eram.

Já os libertos eram os que, tendo nascidos escravos, conseguiram a liberdade, por alforria ou outro processo de manumissão. Desse modo, ao dispor sobre os que conseguiam adquirir o status libertatis, a Constituição admite, tacitamente, a existência de escravos.

Os libertos, porém, já usufruindo do status libertatis, não tinham o status activus civitatis, ou seja, o direito político típico do eleitor, consoante o art. 94 da Constituição:

Art. 94: Podem ser Eleitores, e votar na eleição dos Deputados, Senadores, e Membros dos Conselhos de Província todos, os que podem votar na Assembléia Paroquial. Excetuam-se

I. Os que não tiverem de renda liquida anual duzentos mil réis por bens de raiz, industria, comércio, ou emprego.

II. Os Libertos.

Os libertos, então, como já se disse, seriam aqueles dotados de uma cidadania passiva pela qual uma pessoa, ainda que livre, mas dependente de outrem, tem os direitos civis, mas não a totalidade dos direitos políticos.

O conceito de cidadania passiva foi assim descrito por Kant (1988):

Cette dernière qualité rend nécessaire la distinction entre citoyen actif et passif, même si cette dernière notion peut sembler contradictoire avec celle de citoyen tout court. Les exemples suivants peuvent faire lever cette difficulté : le compagnon chez un marchand ou un artisan ; le domestique (sauf celui qui est au service de l'État); le mineur (naturaliter vel civiliter); toute espèce de gent féminine, ainsi que, de manière générale, tous ceux qui sont contraints de faire dériver leur 
existence (nourriture et assistance) non de leur propre activité, mais de la disposition d'autrui, sont dépourvus de personnalité civile et leur existence n'est, pour ainsi dire, qu'une simple inhérence (\$ 46).

Esta última qualidade torna necessária a distinção entre cidadão ativo e passivo, mesmo se essa última noção possa parecer contraditória com aquela do cidadão como tal. Os exemplos a seguir podem pôr fim a esta dificuldade: o companheiro (aprendiz) de um comerciante ou artesão; o doméstico (exceto se ele está a serviço do Estado); o menor (por natureza ou por condição civil); toda a espécie de pessoa feminina, assim que, de modo geral, todos os que são obrigados a fazer derivar sua existência (alimentação e assistência) não de sua própria atividade, mas da disposição de um outro, são desprovidos de personalidade civil e sua existência não é, por assim dizer, senão uma simples inerência. (\$46) (livre tradução do autor)

Os libertos, como se viu, pelo conjunto do ordenamento legal, poderiam votar apenas nas eleições primárias (paroquiais). A interdição ao voto posterior ao das primárias, aparentemente desconforme com o inciso XIV do art. 179 pelo qual todo cidadão pode ser admitido aos cargos públicos, civis, políticos e militares, sem outra diferença que não seja a dos seus talentos e virtudes, se desfaz com a vigência de um ordenamento vindo dos tempos da Colônia. ${ }^{33}$

A Lei de 20 de outubro de 1823 determinava, em seu art. 1o, a continuidade da aplicação das Ordenações Filipinas de 1603 já que o Código Civil só foi elaborado em 1916, após inúmeros projetos, desde o Império.

No caso, a interdição ao liberto como eleitor advinha de um dispositivo das Ordenações Filipinas, vigentes em boa parte durante o Império, pelo qual um ex-escravo, agora liberto, poderia ser reescravizado pelo estatuto da ingratidão. O $\S 7 \mathrm{o}$, do título 67 , livro 4o das Ordenações Filipinas dispunha:

Se alguém forrar seu escravo, livrando-o de toda a servidão, e depois que for forro, cometer contra quem o forrou alguma ingratidão pessoal em sua presença ou em absência, quer seja verbal, quer seja de feito e real, poderá este patrono revogar a liberdade, que deu a este liberto, e reduzi-lo à servidão, em que antes estava. E bem assim por cada uma das outras causas de ingratidão, porque o doador pode revogar a doação feita ao donatário. ${ }^{34}$

Isto significa, pois, uma alforria concedida, havendo a possibilidade do eventual retorno à condição de escravo, ou seja, a capitis diminutio maxima. Com isso, há uma indução do liberto a ser obediente ao seu doador. Desse modo, ao liberto, não se aplica a plenitude da inviolabilidade dos direitos civis e políticos dos cidadãos brasileiros, que tem por base a liberdade...posta no caput do art. 179. Eventuais talentos e virtudes do inciso XIV do art. 179 pouco significariam em face da perda do status civitatis. Como assinalam Gondra e Schueler (2008):

${ }^{33}$ A expressão do inciso XIV do art. 179 é igual à continuação do já citado art. 6o da Declaração de 1789: Tous les citoyens étant égaux à ses yeux sont également admissibles à toutes dignités, places et emplois publics selon leur capacité, et sans autre distinction que celle de leurs vertus et de leurs talents...

34 O Código Civil de 2002, lei n. 10.406, mantém, nos art. 555-557, a revogação da doação (deserdação) na relação doador-donatário, quando haja ingratidão ou uma indignidade da parte do segundo para com o primeiro. Isto pode ocorrer em caso de sucessão na herança familiar. 
Assim, do ponto de vista jurídico, os libertos, embora brasileiros, sofriam uma série de restrições no que se refere aos direitos políticos. Quanto ao exercício de outras capacidades jurídicas, como direitos civis e obrigacionais, o acesso à instrução pública, a condição jurídica do liberto permanecia ambígua e indefinida em decorrência da multiplicidade de formas assumidas pela experiência da escravidão no Brasil. (p. 236)

A lei do Ventre Livre, lei n. 2040 de 1871, em seu art. 2o, §9o revogou essa possibilidade de retorno à condição de escravo, in verbis:

$\S 9^{\circ}$ Fica derrogada a Ord. liv. $4^{\circ}$, titl 63, na parte que revoga as alforrias por ingratidão.

A Lei do Ventre Livre possibilitou ao escravo a compra da carta de alforria. A chegada ao status libertatis doravante contava com uma positivação jurídica que dava aos escravos, tendo recursos, o acesso à liberdade e, nesse caso, os senhores não poderiam se opor.

Esta lei, entretanto, não alterou a disposição que excluía os libertos dos direitos políticos. A possibilidade da plenitude do status activus civitatis só viria com a Lei Áurea em 1888, pois o Decreto n. 3.209 de janeiro de 1881, mais conhecido como Lei Saraiva ${ }^{35}$, continuava restritiva uma vez que, em seu art. 8o, dispunha, para efeito de revisão do alistamento geral dos eleitores, em todo o Império:

II - De serem incluídos no dito alistamento os cidadãos que requererem e provar em ter adquirido as qualidades de eleitor da conformidade com esta lei, e souberem ler e escrever.

$\S 1^{\circ}$ A prova de haver o cidadão atingido a idade legal será feita por meio da competente certidão; e a de saber ler e escrever pela letra e assinatura do cidadão que requerer a sua inclusão no alistamento, uma vez que a letra e firma estejam reconhecidas por tabelião no requerimento que para este fim dirigir.

Dadas as enormes dificuldades de acesso à instrução primária gratuita por parte dos libertos, não é de se espantar que esse status activus civitatis não se realizaria tão cedo.

Assim, pode-se afirmar que, do ponto de vista jurídico, a Constituição Imperial classificava os habitantes do país em ingênuos, libertos, e estrangeiros ${ }^{36}$. Já as leis

35 Não confundir com a Lei Saraiva/Cotegipe, lei n. 3.270 de 1885, mais conhecida como Lei dos Sexagenários que regulava a extinção gradual do elemento servil e propiciava a liberdade aos escravos, com 60 ou mais anos de idade. Era uma lei muito complicada, seja pela obrigatoriedade de matrícula, seja pela indenização prevista. Conforme o art. 3o dessa lei, haveria indenização: Os escravos inscritos na matrícula serão libertados mediante indenização de seu valor pelo fundo de emancipação ou por qualquer outra forma legal. Para uma análise, cf. Mendonça, 2018.

${ }^{36}$ A Constituição Imperial fazia uma distinção entre os nascidos em Portugal e os de outros países. Os estrangeiros naturalizados tinham direito a voto nas eleições primárias, mas não poderiam ser deputados, ministros de Estado ou sucessores da Coroa. Cf. art. 6, 7, 91, 95, 119, 136. Já os africanos livres que deveriam ser reexportados, eram considerados estrangeiros. Dadas as dificuldades financeiras ou mesmo de obtenção de um lugar para eles na África, houve o Decreto n. 1303 de 1853 declarando que os africanos livres, que tiverem prestado serviços a particulares pelo espaço de 14 anos, sejam emancipados quando o requeiram; com obrigação porém de residirem no lugar que fôr pelo Governo designado, e de tomarem ocupação ou serviços mediante um salário. 
infraconstitucionais adotavam, junto a essa classificação, também os escravos, africanos, forros, crioulos e os indígenas. ${ }^{37}$

Os ingênuos e libertos ainda se subdividiam em cidadãos ativos e passivos, conforme o dispositivo do caput do art. 90 da Constituição. Os livres, a depender da idade e da renda, poderiam gozar do status activus civitatis, pelo qual podiam ser eleitores e eleitos, uma vez que vigia o voto censitário. Já os libertos passaram a ser livres (após a Lei do Ventre Livre) e cidadãos passivos no sentido de não poderem atuar nem como eleitores e nem como eleitos.

Os milhões de escravos, pois, que construíram boa parte das riquezas do país, não faziam parte da comunidade política. Decorrente desta classificação e condições, ao escravo, - não sendo cidadão, (violentamente) definido como res (coisa), proprietas domini (propriedade do senhor), sendo apenas persona (pessoa) quando praticasse um ilícito, - não era permitido o acesso à instrução pública gratuita oficial.

Entrementes, com a Lei n. ${ }^{\circ}$ 2.040, de 28 de setembro de 1871, Lei do Ventre Livre, serão ingênuos também os nascidos da mulher escrava, mas cujo ventre, doravante só ele declarado livre, gerará filhos livres. Ou seja, doravante partus sequitur ventrem passa a ter um sentido peculiar. Estamos, pois, diante de uma anomalia: o ventre da pessoa é livre, mas sua persona ainda está violentada pela res, embora o fruto de seu ventre seja livre. É esse o outro significado do verbete ingênuo (Houaiss, 2009, p. 1083): diz-se de ou filho de escravo nascido livre.

$\mathrm{O}$ acesso à educação viria para os (novos) livres por meio do Decreto n. 5.135 de 1872, cujo teor menciona o termo instrução primária no seu art. 67.

Segundo Ariza (2018), foi só a partir de 1871 que a criança, filha de escravas, tornou-se mais presente no ordenamento jurídico. Até então, diz ela:

Ser criança na Colônia e no Império era, de modo geral, uma condição imprecisa, sobre a qual pesavam leis portuguesas de origem medieval e ideias religiosas, e a concepção da infância como momento particular da vida, merecedor de atenções especiais somente se afirmaria ao longo do século XIX, ainda assim de forma lenta e incompleta. Para as crianças escravas, contudo, o tempo da infância consistia num intervalo breve entre os primeiros anos de vida e o ingresso precoce no mundo do trabalho. (p. 171)

Tanto a lei do Ventre Livre (art. 3o) como o Decreto que o regulamentou (capítulo II) instituíram um Fundo de Emancipação para subsidiar as ações relativas aos livres (ingênuos). Explicitando a mecânica do fundo de recursos para a efetivação da lei, assinala Moura (2013):

O Fundo de Emancipação era constituído pelas taxas dos escravos, pelos impostos gerais sobre a transmissão da propriedade dos escravos, pelo produto de seis loterias anuais, isentas de impostos, $e$ pela décima parte das que forem concedidas de ora em diante para concorrerem na capital do Império, pelas multas impostas em virtude desta lei, pelas quotas que sejam marcadas no Orçamento Geral e nos provinciais e municipais, e pelas subscrições, doações e legados com esse destino. (p. 163-164)

Mas, dada a anômala condição de escrava da mãe, houve várias condicionalidades para a real execução da lei do Ventre Livre. Assim, vale citar alguns artigos do Decreto:

\footnotetext{
${ }^{37}$ Sobre uma iniciativa da Província de Pernambuco abrindo um internato com escola para negros, índios e brancos a partir de 1974, cf. Arantes, 2009.
} 
Art. $5^{\circ}$ Os filhos da mulher escrava, livres pela lei, ficarão em poder e sob a autoridade dos senhores de suas mães até á idade de 8 ou de 21 anos, conforme as condições da mesma lei. ${ }^{38}$

Art. $6^{\circ}$ Até á idade de 8 anos completos, os senhores das mães são obrigados a criá-los e a tratá-los (Lei - art. $1^{o} \S 1^{o}$ ), sob pena de pagarem, desde o dia do abandono, salvo o caso de penúria, os alimentos que, a prudente arbítrio, forem taxados pelo juízo de órfãos, até que os menores sejam entregues a alguma das associações mencionadas na lei, às casas de expostos ou às pessoas que forem encarregadas de sua educação. ${ }^{39}$

Também com relação à prestação de serviços e à alimentação dos filhos de escravas dispõe o conteúdo do decreto:

Art. 18. Cessa a prestação dos serviços dos filhos das escravas, antes de atingirem eles a idade de 21 anos, se, por sentença do juízo criminal, reconhecer-se que os senhores das mães os maltratam, infligindo-lhes castigos excessivos. (Lei-art. $1^{\circ} \S 6^{\circ}$ )

Art. 19. A privação de alimentos, ou a sujeição a atos imorais, produzirá efeito igual ao do artigo antecedente.

(...)

Art. 22. Incumbe também aos senhores criar e tratar os filhos que as filhas livres de suas escravas tenham durante o prazo da prestação de serviços. (Lei - art. $1^{o} \S 3^{\circ}$ ).

O decreto institui, ainda, um fundo financeiro, no Art. 25, para que os governos pudessem sustentar os filhos de escravas, isto é, seriam assumidos pelos poderes públicos. O fundo também serviria para atender ao disposto no Art. 64:

Art. 64. Os juízes de órfãos poderão entregar a associações autorizadas pelo governo os filhos de escravas, nascidos desde a data da lei que sejam cedidos ou abandonados pelos senhores, ou tirados do poder destes em virtude dos arts. 18 e 19 do presente regulamento. (Lei-art. $2^{\circ}$ )

Às associações também poderiam ser entregues, segundo a Lei - art. $1^{o} \S 3^{o}$, os filhos das filhas livres de escravas e, na sua falta, os menores poderiam ser entregues às casas de expostos, ou a particulares, aos quais os juízes de órfãos encarregarão a sua educação. (Lei - art. $2^{o} \S 3^{\circ}$ )

Em troca, porém, as associações, as casas de expostos, ou os particulares teriam direito ao aluguel de serviços gratuitos dos menores até á idade de 21 anos (Art. 65).

O governo, por seu turno, garantiria uma espécie de educação profissional agrícola para os libertos e facultaria às associações a concessão gratuita de terrenos devolutos, para a fundação de colônias agrícolas ou estabelecimentos industriais, em que sejam empregados os libertos e se cure da educação dos menores (Art. 74).

$\mathrm{O}$ artigo 67 dispunha sobre a fiscalização:

\footnotetext{
${ }^{38}$ De acordo com Bobbio (1986a, p. 61-62), há três fundamentos das obrigações e deveres: Três são os tipos clássicos de fundamento das obrigações, como bem o sabem os juristas: ex generatione, ex delictu, ex contractu. A obrigação do filho obedecer ao pai e à mãe depende do fato de que foi por eles gerado... (grifos do autor). No caso em tela, a tutela pelo senhor mantém praticamente a obrigação de obedecê-lo como se cativo ainda fosse. É como se a obrigação humana advinda do ex generatione se deslocasse para o senhor.

${ }^{39}$ Sobre a Casa dos Expostos, cf. Moura (2013), p. 91-92
} 
Art. 67. O juiz de órfãos fiscalizará a instrução primaria e a educação religiosa dos menores, quer exigindo das associações, das casas de expostos e dos particulares o cumprimento dessa obrigação, quer impondo-a aos locatários de serviços nos respectivos contratos.

E, finalmente, é revogado o estatuto da ingratidão ${ }^{40}$ :

Art. 94. Fica derrogada a Ord. Liv. $4^{\circ}$, Tit. 63, na parte que revoga as alforrias por ingratidão. (Lei - art. $\left.4^{o} \S 2^{\circ}\right)$

Pelo teor do Decreto, algumas observações podem ser feitas. Uma mais ampla é dada por Campello (2018)

Somente com o advento da Lei do Ventre-Livre (Lei $n^{\circ} 2.040$, de 28 de setembro de 1871), o escravo passou realmente a adquirir o direito à sua alforria, independentemente da manifestação de vontade do seu senhor. Esse diploma legal criou uma regulamentação civil mínima para os escravos, assegurando-lhes uma gama de direitos (...)De modo geral, antes do advento da Lei do Ventre-Livre, não era possível que o escravo construísse patrimônio próprio sem que houvesse o consentimento do seu dominus. (posição 3819) ${ }^{41}$

Mesmo assim, lembra-nos Mendonça (2018:

Os arquivos históricos do Judiciário em todo o país estão repletos de autos dessa natureza, evidenciando que a lei, mesmo tendo sido oportuna para os senhores, causou-lhes igualmente muita apreensão, devido à atuação de escravos que pelejavam nos tribunais. (p. 282 $)^{42}$

Ao lado dessa possibilidade de alforria pela qual o escravo não está mais sujeito ao estatuto da (in)gratidão, os filhos são livres. Doravante são ingênuos, nascidos livres, bem como os descendentes destes. Contudo, devido à idade e à situação anômala (mãe escrava/filho livre), os filhos são livres, conquanto tutelados, ora pelos senhores das mães (não mais proprietários das crianças), ora por associações de emancipação, ou pela casa de expostos ou mesmo por particulares. Moura (2013) traz uma síntese crítica com relação a este Fundo:

Esse fundo nada mais foi que um emaranhado de normas jurídicas, administrativas e burocráticas para, de um lado, dificultar ao máximo a possibilidade de o escravo conseguir a emancipação de, de outro, criar toda uma sistemática de corrupção na distribuição dos fundos arrecadados. (p. 164)

\footnotetext{
${ }^{40}$ No caso dos libertos, a ingratidão era tida como uma falta grave cometida, como um delito. Essa herança do Direito Romano presente nas Ordenações, possibilita ao senhor tornar o liberto voltar à condição anterior de cativo. Consoante visto acima com Bobbio (1986a, p. 62), um dos fundamentos da obrigação de o escravo obedecer ao dono é o princípio do ex delictu.

${ }^{41}$ Com este artigo, a manumissão, pela qual um escravo obtinha a alforria, deixava de ser um "direito" costumeiro e passa a ser regulamentado pelo Estado por meio de uma positivação escrita. Mas atente-se que a formação dessa poupança, antes dessa lei, se fazia por consentimento do senhor. Havendo, porém, soma reservada, o escravo adquiria o direito à compra de sua liberdade.

${ }^{42}$ As ações de Luiz Gama (1830-1882) se pautaram por essa incansável luta pela liberdade para quem uma abolição, de fato e de direito, deveria garantir igualdade de direitos, reforma agrária e educação para crianças.
} 
Sobre o acesso à instrução pública após a Lei do Ventre Livre, Schuler (1997, 1999 e 2001) mostra que essa Lei previa a educação dos "ingênuos" quando estes fossem entregues ao governo pelos senhores de escravos com o encaminhamento dos filhos do ventre livre para a instrução primária e posteriormente para as escolas de ofícios visando "disciplinar os libertos". A matrícula nos Asilos de Meninos era solicitada por muitos senhores de escravos como forma de indenização pelos gastos que tinham com as crianças libertas pela Lei.

De certo modo, é o que avaliza Salles (2007), quando identifica nos documentos estudados que, na composição dos gestores da irmandade de "pretos crioulos" a figura do tesoureiro:

(...) era sempre branco, porquanto necessitavam que soubesse ler e escrever, o que não ocorria com os pretos, quase sempre analfabetos (p. 78).

Os estudos já feitos sobre esta educação/instrução primária, a partir da Lei do Ventre Livre, parecem confirmar que esta preocupação com a instrução das crianças, dessas crianças agora livres, era precária.

Desse modo, Fonseca (2002), investigando documentos de época constata, nos Relatórios do Ministério da Agricultura, não mais que 113 ingênuos, dos 403.827 nascidos até 1884 como tais, como estando registrados e sob o cuidado do Estado Imperial.

Esse número baixo expressa os limites fáticos dessa lei.

Analisando, em base a arquivos da província da Bahia e ao sentido da lei do Ventre Livre, Mattoso (1988) aponta as ambiguidades dessa Lei:

Para os redatores da lei 28 de Setembro, atrás do "menor" a proteger escondia-se o bom trabalhador, útil ao seu senhor. A este respeito, o parágrafo 6 do artigo lo da lei é muito instrutivo, porque pretende limitar os abusos exercidos pelos senhores que castigam duramente as crianças-ingênuas-escravas e futuras libertas: "se por sentença do juízo criminal reconhecer-se que os senhores das mães os maltratam..." cessa a prestação de serviços destes! (p. 18)

É o que destaca Ariza (2018):

Os senhores das mães dos "ingênuos" procuravam a todo o custo fraudar os registros obrigatórios de nascimento que comprovavam sua condição de pessoas livres, omitindo ou falseando datas. Além disso, a liberdade prometida era, no mínimo, duvidosa: até os oito anos, eles deveriam permanecer sob a tutela dos proprietários de suas mães; este, então, poderiam optar por oferecê-los a asilos públicos em troca de indenizações de 600 mil-réis, ou por mantê-los e usufruir de seus serviços até os 21 anos. Raros foram aqueles que escolheram as indenizações e entregaram os pequenos ao Estado... (p. 174)

Mesmo assim, segundo Ariza (2018)

Educação não constituía item que lhes atendesse _ ao menos não a educação escolar, mesmo que precária, nos cálculos e nas primeiras letras. O tema da instrução pública, é fato, somente integrou-se à agenda política na metade do século XIX. Vagarosa, a preocupação com a instrução das crianças jamais incluiu os pequenos escravos, 
para quem educação era sinônimo de disciplinamento violento, aprendizado do trabalho e lições de como sobreviver à escravidão recebidas de pais, parentes e nos círculos de solidariedade entre cativos nos quais se criavam. (p. 173)

Importa registrar o Decreto n. 7031-A de 1878 que, criando cursos noturnos para adultos do sexo masculino voltados para a instrução primária dispunha no seu art. 5o:

Art. $5^{\circ}$ Nos cursos noturnos poderão matricular-se, em qualquer tempo, todas as pessoas do sexo masculino, livres ou libertos, maiores de 14 anos. As matriculas serão feitas pelos Professores dos cursos em vista de guias passadas pelos respectivos Delegados, os quais farão nelas as declarações da naturalidade, filiação, idade, profissão e residência dos matriculandos.

Apesar disso, Gonçalves (2000), estudioso do assunto, assim se expressa:

O fato de existirem iniciativas com vistas à inclusão dos escravos e negros livres em cursos de instrução primária e profissional não nos autoriza inferir que essa tenha sido uma experiência universal. (...) Embora tenham existido iniciativas dessa natureza, os registros sobre a participação efetiva dos negros são incipientes. Como muitos desses cursos continuaram a existir após a Abolição, era de se esperar que as barreiras que a mentalidade escravista criara para dificultar a frequência de negros nas aulas noturnas diminuíssem ou desaparecessem. Mas não foi isso que aconteceu. A República não expandiu os direitos políticos imediatamente após sua proclamação, nem garantiu o acesso de todos à educação durante décadas. Agravou-se muito a situação dos negros, que após a Abolição, foram lançados à própria sorte. (p. 327-328)

Se essa situação já era assim, pode-se imaginar o quanto, no futuro, deveria haver de iniciativas de políticas educacionais tendentes a fazer a reparação dessa opressão secular.

\section{Conclusão}

Como se espera ter demonstrado neste estudo, a exclusão do escravo estava posta de modo implícito no ordenamento jurídico imperial, o que redunda numa contradição com o estatuto liberal da Constituição do Império. Apesar da odiosa realidade fática da escravatura, negando ao escravo o status libertatis, em si mesma ela representava uma situação contraditória face um Estado que se pretendia liberal.

Como seres humanos poderiam fazer parte de uma relação em que uns seriam livres (liberi) e outros escravos (servi)? Há uma antinomia radical entre os pressupostos de liberdade e igualdade inerentes ao Liberalismo e a existência do escravo como bem semovente (res) de cujo trabalho forçado muito se construiu como patrimônio no país. A rigor, excluídos dos bens por eles produzidos, estavam justamente incluídos como produtores das riquezas geradas pelo trabalho compelido. A insustentabilidade desta antinomia foi o fator pelo qual o ordenamento jurídico do Império, nas suas dinâmicas interna e externa, viuse pressionado, mesmo que gradualmente, a acolher modificações tendentes à Abolição, no conjunto de suas leis. Assim, como se sabe, de um lado fatores externos como a abolição da 
escravatura nos EUA, no Haiti e em outros países colonizados pela Espanha, a pressão exercida pela Inglaterra para a extinção do tráfico negreiro e, de outro, fatores internos como as lutas dos escravos e dos abolicionistas face à resistência dos senhores de escravos a abrirem mão de suas " propriedades", determinaram a abolição, sob a forma de lei, em 1888. A lei Áurea, no entanto, excluído o tempo da colônia, e se tomarmos como referência a chegada da família real, levou longos 80 anos para ser assinada. O estudo do ordenamento jurídico do Império revela o gradualismo deste processo com severas consequências para os descendentes dos cativos, das quais a exclusão da instrução primária é uma de suas faces.

A instrução primária pública e gratuita, no ordenamento jurídico constitucional do Império, fazia parte das prerrogativas do cidadão, considerado enquanto detentor de direitos civis e políticos. Numa sociedade escravocrata, é evidente que os cativos estariam excluídos dessas prerrogativas, muito embora não estivessem proibidos de se tornarem letrados por meio de outras instituições que não a escola pública, como se pode constatar na bibliografia analisada.

Este estudo procurou demonstrar que, pela Lei do Ventre Livre, houve a incorporação de novos ingênuos, como livres e detentores do status libertatis sob os direitos civis e potencialmente de direitos políticos. No entanto, as prerrogativas ainda mantidas pelos senhores, limitavam, de fato, o alcance do exercício deste status e davam margem a inúmeros subterfúgios responsáveis pela manutenção, mesmo que encoberta, da situação de escravidão tutelada ou, como expresso por Campello (2008) uma servidão mascarada (Posição 6724).

No gradualismo que caracterizou o processo legislativo, pois, aos escravos foi facultada a compra de sua alforria bem como aos senhores a concessão da liberdade aos primeiros. Estamos, então, diante da figura do liberto, disposta na própria Constituição Imperial. Diferentemente dos ingênuos, os libertos assumiam os direitos civis, mas eram excluídos dos direitos políticos. Usufruíam do status libertatis, mas não do status activae civitatis, a não ser restritivamente nas eleições paroquiais. Além do mais, até a lei do Ventre Livre, estavam condicionados pelo estatuto da gratidão.

O termo todos presente na Constituição só abrangeria formalmente a totalidade dos escravos, doravante livres ou ingênuos nos termos da Lei Maior, a partir da lei Áurea de 13/05/1888. Isso significa que, do ponto de vista do ordenamento jurídico, com a declaração da extinção desse odioso instituto, a Constituição Imperial abrigou o todos em uma dimensão de cidadania, defendida por alguns constituintes de 1823 e, especialmente, pelos movimentos sociais abolicionistas que nunca reconheceram a perda do status libertatis como algo "natural ou um mal menor necessário". Só então se erige, do ponto de vista, do direito o que afirma Schnapper (2000):

Ce qui fonde la citoyenneté, c'est l'opposition entre les spécificités de l'homme privé, membre de la société civile, et l'universalisme du citoyen. (p. 27)

$O$ que funda a cidadania é a oposição entre as especificidades do homem privado, membro da sociedade civil e o universalismo do cidadão. (livre tradução do autor)

A correlação entre a instrução pública primária aberta a todos e a cidadania como universalismo do cidadão expresso no critério de direitos civis, políticos e sociais, entretanto, haveria de esperar muito tempo, uma vez que o fim da escravatura não aboliu as desigualdades sociais, a discriminação racial e nem a cultura que as sustentavam. Ainda tardaria muito o acesso aos bens sociais próprios do status civitatis, das prestações estatais no interesse coletivo e individual, entre os quais a educação escolar como direito de todos e deve ser ministrada pela família e pelos poderes públicos conforme o art. 149 da Constituição Federal de 1934. O art. 205 da Constituição de 1988, no entanto, foi o que potencializou a educação como direito de todos e dever do Estado. 
O combate ao racismo, fruto dessas discriminações históricas, e aos preconceitos, só encontraria sua formalização maior nessa última Constituição, a de 1988, em leis infraconstitucionais e em regulamentações normativas. De um lado, na Constituição se fez a estrita condenação ao racismo como crime inafiançável e, de outro, a desconstrução de estereótipos e preconceitos e a afirmação da necessidade de construção de uma cultura individual e institucional de reconhecimento da dívida em relação ao valor do negro na formação da sociedade brasileira. Afinal, resume Schwarcz (2012):

com a voga das teorias raciais, influentes até os anos 1930, caía sobre esses grupos um fardo pesado, condicionado pelos modelos deterministas de interpretação social, que não só estabeleciam hierarquias entre as raças como condenavam a mestiçagem existente no país. (...) a entrada conjunta e maciça dessas teorias fez com que o debate pós-Abolição se afastasse da questão da cidadania e igualdade em nome de razões e argumentos da biologia. (p. 61)

Essa passagem da Abolição para a República, no caso dos ex-cativos, portanto, foi dramática, como assevera Souza (2017):

O ex-escravo é jogado dentro de uma ordem social competitiva, como diz Florestan (Fernandes - CRJC), que ele não conhecia e para qual ele não havia sido preparado. Para os grandes senhores de terra, a libertação foi uma dádiva: não apenas se viram livres de qualquer obrigação com os ex-escravos que antes exploravam, mas puderam "escolher" entra a absorção dos ex-escravos, o uso da mão de obra estrangeira que chegava de modo abundante no país-- cuja importação os senhores haviam conseguido transformar em "política de Estado" -- e a utilização dos nacionais não escravos. Estes últimos haviam evitado os trabalhos manuais como símbolo de degradação quando monopolizados pelos escravos. (p. 75)

Essa afirmação de Fernandes é corroborada por Schwarcz (2012):

A Lei Áurea de 1888, não só deixou de prever ressarcimentos aos proprietários (como esses tantos esperavam), como não priorizou uma política social de amparo a esses grupos sociais que, sem o aprendizado necessário ou a experiência nas cidades, não dispunham das ferramentas primeiras para competir em igualdade de condições com os trabalhadores nacionais livres, ou mesmo com as populações imigrantes que traziam consigo suas especializações e hábitos urbanos. (p. 61)

Voltar-se para estas situações referentes a um contexto distanciado no tempo possibilita o entendimento de novos ordenamentos jurídicos, em especial os relativos à educação, que buscaram reparar, sempre incompleta e imperfeitamente, a violência de um passado que insiste em permanecer. A reparação é uma forma de ressarcir um dano causado por uma situação historicamente marcada pela exclusão e suas consequências nos descendentes. A escravidão, por seu caráter antinatural, é um dano cujos efeitos se fazem presente em nossa sociedade. Esses ordenamentos significam uma direção reparadora da qual fazem parte políticas de reconhecimento. Como posto por Calvès (2005): 
Dans cette première configuration où le groupe cible de la discrimination positive est un groupe historiquement opprimé, les mesures préférentielles dont il se bénéficie revêtent une dimension réparatrice ou compensatrice. Dans la mesure toutefois où la sujétion passée, une fois acquise l'égalité des droits se survit bien souvent à ele-même dans les faits, elles affichent également (dans leur intitulé même...) une dimension contrediscriminatoire qu'il est parfois jugé opportun de présenter de manière plus voilée, en invoquant um objectif d'"intégration", de "mixité" ou encore de "diversité". (p. 12-13) (grifos do autor)

Nessa primeira configuração em que o grupo alvo da discriminação positiva é um grupo historicamente oprimido, as medidas preferenciais das quais ele se beneficia revestem uma dimensão reparadora ou compensadora. Todavia, na medida em que a sujeição passada, uma vez adquirida a igualdade de direitos, sobrevive muitas nos fatos, as medidas mostram igualmente ( em seu próprio enunciado...) uma dimensão contra-discriminatória que, por vezes, é julgada oportuna de apresentá-la de modo mais velado, invocando um objeto de "integração", de "coabitação entre diferentes" ou ainda de "diversidade” (p. 12-13) (tradução livre)

Um caso dessa busca de reparação explícita foi a sanção da lei n. 10.639/2003 que, à luz do art. 242, $\S 1^{\circ}$ da Constituição, inclui, no currículo oficial dos Sistemas de Ensino, a obrigatoriedade da temática História e Cultura Afro-Brasileira. Esse dispositivo foi normatizado pelo Conselho Pleno do Conselho Nacional de Educação mediante o Parecer n.03/2004 e pela Resolução CNE/CP n.01/2004. Essa normatização se viu reforçada pela meta 7, estratégia 7.25 da lei n. 13005/2014, a do Plano Nacional de educação. E a lei n. 12.711/2012 e o Decreto n. 7.824/2012, no âmbito de um critério sócio-econômico, abrangem um percentual de vagas em instituições federais de ensino superior para pretos, pardos $e$ indígenas. Essa forma de reparação é uma das vias que permite a transição de uma cidadania formalizada em lei para uma cidadania substantiva.

Este recorte buscando ampliar a literatura sobre o assunto, à luz do recorte jurídico, associando-se ao conjunto das obras analisadas, é mais um modo pelo qual se retira do silêncio o jugo odioso a que foram submetidos os cativos. Gramsci escrevia que uma das funções do intelectual seria, após o conhece-te a ti mesmo, socializar verdades já conhecidas e torná-las patrimônio de todos. Esse empenho é muitas vezes mais importante do que descobrir uma verdade nova. É nesse sentido que a herança deixada pelo cativeiro em nosso país, merece ser continuamente compreendida. Dominar, pelo conhecimento, tal herança, é não se deixar dominar por ela, ao contrário, dominando-a pode-se buscar vias de superação. Em uma realidade, como a nossa, que ainda convive com uma escolaridade precária, o acesso a informações mais sólidas e mais completas, abre espaços o conhecimento e a exigência de direitos como forma de realizar a cidadania. Na expressão de Clementina de Jesus:

Preto não é mais lacaio/preto não tem mais senhor. 


\section{Referências}

Brasil, Ipea. Documento Base. Primeira Conferência Nacional de Política Indigenista. www.ipea.gov.br/participacao/images/documento-base-online. pdf acesso em 19 de outubro de 2018.

Brasil - Reino. Decreto de 30 de junho de 1821. Permite a qualquer cidadão o ensino, e abertura de escola de primeiras letras, independente de exame e licença. Coleção das Leis do Brasil de 1821 - Parte I. Rio de Janeiro: Imprensa Nacional, 1889.

Brasil - Reino. Lei de 20 de outubro de 1823. Declara em vigor a legislação pela qual se regia o Brasil até 25 de abril de 1821 e bem assim as leis promulgadas pelo senhor D. Pedro, como Regente e imperador daquela data em diante, e os decretos das Cortes portuguesas que são especificados. Leis da Assembléia Geral Constituinte e Legislativa de 1823. Coleção das Decisões do Governo do Império do Brasil de 1823 - Parte II. Rio de Janeiro: Imprensa Nacional, 1887.

Ordenações Filipinas. www1.ci.uc.pt/ihti/proj/filipinas/ordenacoes/htm acesso em 04 de setembro de 2018.

Albuquerque, Wlamyra. Movimentos Sociais Abolicionistas. In: Schwarcz Lilia M. e Gomes Flávio. (org) Dicionário da Escravidão e Liberdade. São Paulo : Cia das Letras, 2018, p. 328-333.

Algranti, Leila Mezan. O feitor ausente: estudo sobre a escravidão urbana no Rio de Janeiro, 1808 - 1822. Petrópolis: Vozes, 1988.

Alves, Silvana Rodrigues Leite. A instrução pública em Indaiatuba: 1854-1930. Contribuição para a história da educação brasileira. Dissertação de Mestrado. Campinas, SP, Faculdade de Educação, Universidade Estadual de Campinas, 2007, 180 p.

Arantes, Adlene Silva. Colônia Orfanológica Isabel: uma escola para negros, índios e brancos (Pernambuco 1874 -1889) Revista Brasileira de História da Educação. Vol. 20, maio/ago, 2009, p.105-136.

Ariza, Marilia. B. A. Crianças/Ventre Livre. In: Schwarcz Lilia M. e Gomes Flávio. (org) Dicionário da Escravidão e Liberdade. São Paulo: Cia das Letras, 2018, p. 169-175.

Assis, Machado. Obra Completa de Machado de Assis. Crônicas: Bons Dias. 19 de maio de 1888. Rio de Janeiro: Nova Aguilar, vol. 3, 1994.

Azevedo, Célia Maria Marinho de. Onda negra, medo branco: o negro no imaginário das elites século XIX. São Paulo: Paz e Terra, 1987.

Barros, Surya Pombo de. Escravos, libertos, filhos de africanos livres, não livres, pretos, ingênuos: negros nas legislações educacionais do XIX. Educação e Pesquisa., São Paulo, v. 42, n. 3, p. 591-605, jul./set. 2016. https://doi.org/10.1590/S1517-9702201609141039

Barros, Surya Aaronovich Pombo de. Negrinhos que por ahi andão: a escolarização da população negra em São Paulo (1870-1920). Dissertação de Mestrado. São Paulo, SP, Universidade de São Paulo, Faculdade de Educação, 2005, 163 p.

Bobbio, Norberto. O futuro da democracia: uma defesa das regras do jogo. Rio de Janeiro: Paz e Terra. 1986. 
Bobbio, Norberto, Bovero, Michelangelo. Sociedade e Estado na Filosofia Política Moderna. São Paulo: Brasiliense, 1986a.

Bobbio, Norberto. A Era dos Direitos. Rio de Janeiro: Campus, 1992.

Boschi, Caio César. Os Leigos e o Poder: irmandades leigas e política colonizadora em Minas Gerais. São Paulo: Editora Ática, 1986.

Bovero, Michelangelo. Contra a democracia dos piores: uma gramática da democracia. Campus, Rio de Janeiro: 2002.

Bueno, Francisco da Silveira. Grande Dicionário Etimológico-Prosódico da Língua Portuguesa. 4o volume, São Paulo: Editora Lisa, 1988.

Calvès, Gwénäele. La discrimination positive. Paris: PUF, 2005.

Campello, André Barreto. Manual Jurídico da Escravidão: Império do Brasil. ebook, Paco e Littera, Jundiaí, 9788546212088, 2018, Edição do Kindle.

Campello, André Emmanuel Batista Barreto. A Escravidão no Império do Brasil: perspectivas jurídicas. Disponível em: https://www.sinprofaz.org.br/artigos/a-escravidao-no-imperio-do-brasilperspectivas-juridicas/. Acesso em 14 de outubro de 2018.

Cândido, Priscila Mariano; SANTOS, Claudia Rejane Schavarinski Almeida. Educação para escravos e libertos: reflexões sobre a instrução pública no século XIX. VOOS Revista Polidisciplinar Eletrônica da Faculdade Guairacá, vol. 05, ed. 02, 2013, p. 14-30. (Caderno de Ciências Humanas).

Cardoso, Marcos A. O movimento negro. Belo Horizonte: Mazza, 2002.

Carta Régia de 1798. http://lemad.fflch.usp.br/sites/lemad.fflch.usp.br/files/201804/A_carta_regia_de_12_de_maio_de_1798B.pdf Acesso em 06 de novembro de 2018.

Casimiro, Ana Palmira Bittencourt Santos. Pensamentos fundadores na educação religiosa do Brasil Colonial. www.histedbr.fae.unicamp.br Acervo de fontes. Acervo navegando na História da Educação Brasileira - Colônia, Período Jesuítico. Acesso em 17 de novembro de 2018.

Castro, Hebe Maria Mattos de. Das cores do silêncio: os significados da liberdade no sudeste escravista do Brasil século XIX. Rio de Janeiro: Arquivo Nacional, 1995.

Chizzotti, Antonio. As origens da instrução pública no Brasil. Dissertação (mestrado) - PUC-SP, São Paulo, 1975.

Chizzotti, Antonio. A Constituinte de 1823 e a Educação. In: Fávero, Osmar (org). A educação nas Constituintes Brasileiras. Campinas: Autores Associados, 1996. p. 31 -54.

Comparato, Fábio Konder. A Afirmação Histórica dos Direitos Humanos. São Paulo: Saraiva, 2004.

Costa, Moacir Lobo da. O direito público subjetivo e a doutrina de Duguit. Revista da Faculdade de Direito da Universidade de São Paulo. n.47, p.409-502, 1951. https://doi.org/10.11606/issn.2318-8235.v47i0p490-502 
Cruz, Mariléia dos Santos. Políticas de ações negativas e aspirações de famílias negras pelo acesso à escolarização na província do Maranhão no século XIX. Revista Brasileira de História da Educação, nº. 20, mai./ago. 2009, p. 73-104.

Cunha, Luiz Antônio. A Educação Brasileira na Primeira Onda Laica: do Império à República. Rio de Janeiro: Edição do Autor, 2017. p. 130-139.

Diretório dos índios. https://www.nacaomestica.org/diretorio_dos_indios.htm acesso em 6 de novembro de 2018.

Dossiê: Negros e a Educação. Revista Brasileira de História da Educação. vol, 2, n.2 (4), jul/dez de 2002.

Felicio, Laura Stocco. A instrução dos ingênuos: a Lei do Ventre Livre e a educação dos negros no Brasil Império (1871-1889 Iniciação científica (Graduando em História) - Faculdade de Filosofia, Letras e Ciências Humanas - USP - 2016.

Fonseca, Monica Cristina da. O Debate sobre a educação dos ingênuos na Bahia (1871-1889). Programa de Pós-Graduação Educação da Universidade Federal da Bahia. Dissertação de Mestrado, 2014. 149 pgs.

Fonseca, Marcus Vinicius. As Primeiras Práticas Educacionais com Características Modernas em Relação aos Negros no Brasil. In: Fonseca, Marcus Vinicius et al (Orgs.). Negro e educação: presença do negro no sistema educacional brasileiro. São Paulo: Ação Educação/Anped/Fundação Ford, 2001.

Fonseca, Marcus Vinicius. A educação dos negros: uma nova face do processo de escravidão no Brasil. Bragança Paulista: EDUSF, 2002.

Gonçalves, Luiz Alberto Oliveira. Negros e Educação no Brasil. IN: Lopes, Eliana Martha Teixeira; Faria Filho, Luciano Mendes de e Greive, Cynthia. 500 anos de educação no Brasil. Belo Horizonte: Autêntica, 2000.

Gondra, José Gonçalves e Schueler, Alessandra. Educação, poder e sociedade no Império Brasileiro. São Paulo: Cortez, 2008.

Jellineck, Georg. Sistema dei diritti publici subbietivi. Milano: Società Editrice Libraria, 1912.

Kant Immanuel. La métaphysique des moeurs, doctrine du droit. Paris: PUF, 1988.

Kant Immanuel. Fundamentação Metafísica dos Costumes. Lisboa: Edições 70, 2007.

Houaiss, Antônio e Villar, Mauro de. Dicionário Houaiss da Língua Portuguesa. Rio de Janeiro: Objetiva, 2009.

Libby, Douglas Cole e Furtado, Júnia Ferreira (org). Trabalho Livre e Trabalho Escravo: Brasil e Europa, séculos XVIII e XIX. São Paulo: AnnaBlume, 2006.

Mamigonian, Beatriz Gallotti e Grinberg, Keila. Lei de 1831. In: Schwarcz Lilia M. e Gomes Flávio. (org) Dicionário da Escravidão e Liberdade. São Paulo: Cia das Letras, 2018, p. 285-291. 
Mamigonian, Beatriz Gallotti. Estado Nacional e a instabilidade da propriedade escrava: a lei de 1831 e a matrícula dos escravos de 1872. Almanack. Guarulhos, n.02, p.20-37, $2^{\circ}$ semestre de 2011. https://doi.org/10.1590/2236-463320110203

Marcílio, Maria Luiza. A roda dos expostos e a criança abandonada na História do Brasil. 17261950. In.: FREITAS, Marcos Cezar de (org.). História Social da Infância no Brasil. 6. ed - São Paulo: Cortez, 2006, p. 53-80.

Martinez, Alessandra Frota. Educar e instruir: a instrução popular na Corte imperial. 1870 - 1889. Dissertação de Mestrado, Niterói, Universidade Federal Fluminense, 1997.

Martins Filho, Ives Gandra da Silva. O Ordenamento Jurídico Brasileiro. Revista Jurídica Virtual. Brasília, vol. 1, n. 3, julho, 1999.

Marshall, Thomas Humphrey. Cidadania, Classe Social e Status. Rio de Janeiro: Zahar, 1967.

Mattos, Hebe e Gringberg, Keila. Código Penal escravista e Estado. In: Schwarcz Lilia M. e Gomes Flávio. (org) Dicionário da Escravidão e Liberdade. São Paulo : Cia das Letras, 2018, p.163-168.

Mattoso, Kátia de Queirós. O Filho da Escrava (em torno da Lei do Ventre Livre). Revista Brasileira de História. vol. 8, n. 16, mar/ago, 1988, p. 37-55.

Mello,Francisco Ignacio Marcondes Homem de. A Constituinte perante a História. Brasília: Senado Federal, 1996. (Cópia fac-símile da edição de 1863).

Mendonça, Joseli Maria Nunes. Legislação Emancipacionista, 1871 e 1885. In: Schwarcz Lilia M. e Gomes Flávio. (org) Dicionário da Escravidão e Liberdade. São Paulo: Cia das Letras, 2018, p.277-284.

Mendonça, Ana Waleska Pollo Campos e Vasconcelos, Maria Celi Chaves. A Gênese do Conceito de Educação Pública. In: RAMOS, Lílian (org) Igreja, Estado e Educação no Brasil. Rio de Janeiro: Virtual, 2005.

Moore Jr, Barrington. As origens sociais da ditadura e da democracia. São Paulo: Martins Fontes, 1975.

Moraes, Christianni Cardoso. Ler e escrever: habilidades de escravos forros? Comarca do Rio das Mortes, Minas Gerais, 1731-1850. Revista Brasileira de Educação, v.12, n.36, set./dez. 2007, p. 493-504. https://doi.org/10.1590/S1413-24782007000300008

Moura, Clóvis. Dicionário da Escravidão Negra no Brasil. São Paulo: EDUSP, 2013.

Nogueira, Vera Lúcia. População negra, escravismo e educação no Brasil: séculos XIX e XX. Belo Horizonte: Mazza, 2015.

Oliveira, Ana Guerra Ribeiro de. Pena, Papel e Grilhões: o sinuoso caminho até a aprovação do lei do ventre livre. Faculdade Direito da UFMG, 2016, 160 p.

Perussatto, Melina Kleinert. Filhos livres das escravas: trabalho e instrução no processo emancipacionista - Rio Pardo/RS. Ephis, I Encontro de Pesquisas Históricas - PUC RS, Oficina do Historiador, Porto Alegre, Revista Discente do Programa de Pós-Graduação em História - PUC RS, mai. 2014, p. 1301-1312. 
Ribas, Antonio Joaquim. Curso de Direito Civil Brasileiro. Tomo I, Rio de Janeiro: Garnier, 1880.

Ribeiro, Cristiane Maria. Da exclusão a invisibilidade: a educação dos negros goianos 1835-1920. Multi-Science Journal, v.1, n.13, 2018, p.365-373. https://doi.org/10.33837/msj.v1i13.658

Rizzini, Irene. A institucionalização de crianças no Brasil: percurso histórico e desafios do presente. Rio de Janeiro: Ed PUC-Rio; São Paulo: Loyola, 2004.

Rocha, Fernanda Franco. Cultura e educação de crianças negras em Goiás (1871-1889). Dissertação de Mestrado. Goiânia, GO, Universidade Católica de Goiás, 2007, 120 p.

Salles, Fritz Teixeira de. Associações Religiosas no Ciclo do Ouro. São Paulo : Perspectiva, 2007.

Santos, Martha S. "Slave Mothers", Partus Sequitur Ventrem, and the Naturalization of Slave Reproduction in Nineteenth-Century Brazil" Revista Tempo. vol.22 no.41 Niterói Sept./Dec. 2016. On-line version ISSN 1980-542X Acesso em 15 de outubro de 2018. https://doi.org/10.20509/TEM-1980-542X2016v224106

Sebrão, Graciane Daniela. Presença/ausência de africanos e afrodescendentes nos processos de escolarização em Desterro - Santa Catarina (1870-1888). Dissertação de Mestrado. Florianópolis, Universidade do Estado de Santa Catarina, 2010, 136 p.

Schueler, Alessandra F. Martinez de. Crianças e escolas na passagem do Império para a República. Revista Brasileira de História, v.19. n.37, set., 1999. p.59-84. https://doi.org/10.1590/S0102-01881999000100004

Schueler, Alessandra F. Martinez de. A Associação Protetora da Infância Desvalida e as escolas de São Sebastião e São José: educação e instrução no Rio de Janeiro do século XIX. In.: Monarcha, Carlos (org.). Educação da infância brasileira (1875-1983). Campinas, SP: Autores Associados, 2001, p.157-184.

Schueler, Alessandra Frota Martinez de. A imprensa pedagógica e a educação de escravos e libertos na Corte Imperial: impasses e ambigüidades da cidadania na revista Instrução Pública (1872-1889). Cadernos de História da Educação, nº . 4, jan./dez. 2005, p. 13-25.

Schwarcz, Lilia Moritz. População e sociedade. In: SCHWARCZ, Lilia Moritz. História do Brasil Nação (1808-2010): A abertura para o mundo (1889-1930). Volume 3. Rio de Janeiro: Objetiva, 2021.

Schwarcz Lilia M. e Gomes Flávio. (org) Dicionário da Escravidão e Liberdade. São Paulo: Cia das Letras, 2018.

Silva, Adriana Maria de Paula da. Aprender com perfeição e sem coação: uma escola para meninos pretos e pardos na Corte. Brasília: Editora Plano, 2000.

Silva, Noemi Santos da. Aprender a liberdade: reflexões sobre projetos e práticas de escolarização de escravos, libertos e ingênuos no Paraná (1871-1888). Revista Vernáculo, nº. 28, $2^{\circ}$ sem./2011, p. 149-185. https://doi.org/10.5380/rv.v0i28.33365

Schnapper, Dominique. Qu'est ce que la citoyenneté ? Paris: Gallimard, 2000. 
Souza, Jessé. A elite do atraso: da escravidão à Lava Jato. Rio de Janeiro: Leya, 2017.

Souza, Maria Zélia Maia de. O aprendizado para o trabalho dos meninos desvalidos: nem negros escravos e nem e nem criminosos. IX Congresso Iberoamericano de História da Educação LatinoAmericano, 2009, p. 43-60.

Sposito, Fernanda. Nem cidadãos, nem brasileiros: indígenas na formação do Estado nacional brasileiro e conflitos na província de São Paulo (1822-1845). São Paulo: Alameda, 2012.

Sposito, Fernanda. Liberdade para os índios no Império do Brasil. A revogação das guerras justas em 1831. Almanack. n. 1, p. 52-55, 2011 Guarulhos. https://doi.org/10.1590/2236-463320110105

Symonides, Janusz. (Org.). Direitos humanos: novas dimensões e desafios. Brasília: Unesco, 2003.

Taylor, Claire. Da escravidão à falta de liberdade na Europa Ocidental durante a Alta Idade Média. IN: Libby, Douglas Cole e Furtado, Júnia Ferreira (org). Trabalho Livre e Trabalho Escravo: Brasil e Europa, séculos XVIII e XIX. São Paulo: AnnaBlume, 2006.

Vasconcelos, Maria Celi Chaves. A Casa e seus mestres: a educação no Brasil de Oitocentos. Rio de Janeiro: Griphus, 2004.

Veiga, Cynthia Greive. Conflitos e tensões na produção da inclusão escolar de crianças pobres, negras e mestiças, Brasil, século XIX. Educação em Revista, v.26, p.263-286, 2010. https://doi.org/10.1590/S0102-46982010000100013

Veiga, Cynthia. Escola pública para os negros e os pobres no Brasil: uma invenção imperial. Revista Brasileira de Educação, vol. 13, no. 39, 2008, Editorial Associação Nacional de PósGraduação e Pesquisa em Educação. pg. 502-516. https://doi.org/10.1590/S1413$\underline{24782008000300007}$

Xenofonte, Mauro Artur Oliveira; Gondim, Cícero Ricardo Grangeiro; Eustáquio, Maria do Carmo Gomes. Da senzala à sala de aula: a condição do negro na história da educação brasileira entre 1871 e 1888. Acta Historia Educere, v.1, n.2, 2017, p. 3-31.

Wissenbach, Maria Cristina Cortez. Letramento e escolas. In: Schwarcz Lilia M. e Gomes Flávio. (org) Dicionário da Escravidão e Liberdade. São Paulo: Cia das Letras, 2018. 